\title{
Size distributions and dry deposition fluxes of water-soluble inorganic nitrogen in atmospheric aerosols in Xiamen Bay, China
}

\author{
Shui-Ping Wu, et al. [full author details at the end of the article]
}

Received: 28 July 2021 / Accepted: 29 September 2021 / Published online: 11 October 2021

(c) The Author(s), under exclusive licence to Springer Nature B.V. 2021

\begin{abstract}
Size-segregated aerosol particles were collected using a high volume MOUDI sampler at a coastal urban site in Xiamen Bay, China, from March 2018 to June 2020 to examine the seasonal characteristics of aerosol and water-soluble inorganic ions (WSIIs) and the dry deposition of nitrogen species. During the study period, the annual average concentrations of $\mathrm{PM}_{1}, \mathrm{PM}_{2.5}, \mathrm{PM}_{10}$, and TSP were 14.8 $\pm 5.6,21.1 \pm 9.0,35.4 \pm 14.2 \mu \mathrm{g} \mathrm{m}^{-3}$, and $45.2 \pm 21.3 \mu \mathrm{g} \mathrm{m}^{-3}$, respectively. The seasonal variations of aerosol concentrations were impacted by the monsoon with the lowest value in summer and the higher values in other seasons. For WSIIs, the annual average concentrations were $6.3 \pm 3.3,2.1 \pm 1.2,3.3 \pm 1.5$, and $1.6 \pm 0.8 \mu \mathrm{g} \mathrm{m}^{-3}$ in $\mathrm{PM}_{1}, \mathrm{PM}_{1-2.5}, \mathrm{PM}_{2.5-10}$, and $\mathrm{PM}_{>10}$, respectively. In addition, pronounced seasonal variations of WSIIs in $\mathrm{PM}_{1}$ and $\mathrm{PM}_{1-2.5}$ were observed, with the highest concentration in spring-winter and the lowest in summer. The size distribution showed that $\mathrm{SO}_{4}{ }^{2-}, \mathrm{NH}_{4}{ }^{+}$and $\mathrm{K}^{+}$were consistently present in the submicron particles while $\mathrm{Ca}^{2+}$, $\mathrm{Mg}^{2+}, \mathrm{Na}^{+}$and $\mathrm{Cl}^{-}$mainly accumulated in the size range of $2.5-10 \mu \mathrm{m}$, reflecting their different dominant sources. In spring, fall and winter, a bimodal distribution of $\mathrm{NO}_{3}{ }^{-}$was observed with one peak at 2.5-10 $\mu \mathrm{m}$ and another peak at $0.44-1 \mu \mathrm{m}$. In summer, however, the fine mode peak disappeared, likely due to the unfavorable conditions for the formation of $\mathrm{NH}_{4} \mathrm{NO}_{3}$. For $\mathrm{NH}_{4}{ }^{+}$and $\mathrm{SO}_{4}{ }^{2-}$, their dominant peak at $0.25-0.44 \mu \mathrm{m}$ in summer and fall shifted to $0.44-1 \mu \mathrm{m}$ in spring and winter. Although the concentration of $\mathrm{NO}_{3}-\mathrm{N}$ was lower than $\mathrm{NH}_{4}-\mathrm{N}$, the dry deposition flux of $\mathrm{NO}_{3}-\mathrm{N}\left(35.77 \pm 24.49 \mu \mathrm{mol} \mathrm{N} \mathrm{m}{ }^{-2} \mathrm{~d}^{-1}\right)$ was much higher than that of $\mathrm{NH}_{4}-\mathrm{N}\left(10.95 \pm 11.89 \mu \mathrm{mol} \mathrm{N} \mathrm{m}{ }^{-2} \mathrm{~d}^{-1}\right)$, mainly due to the larger deposition velocities of $\mathrm{NO}_{3}-\mathrm{N}$. The contribution of sea-salt particles to the total particulate inorganic $\mathrm{N}$ deposition was estimated to be $23.9-52.8 \%$. Dry deposition of particulate inorganic $\mathrm{N}$ accounted for $0.95 \%$ of other terrestrial $\mathrm{N}$ influxes. The annual total $\mathrm{N}$ deposition can create a new productivity of $3.55 \mathrm{mgC} \mathrm{m}^{-2} \mathrm{~d}^{-1}$, accounting for $1.3-4.7 \%$ of the primary productivity in Xiamen Bay. In light of these results, atmospheric $\mathrm{N}$ deposition could have a significant influence on biogeochemistry cycle of nutrients with respect to projected increase of anthropogenic emissions from mobile sources in coastal region.
\end{abstract}

Keywords Water-soluble inorganic nitrogen $\cdot$ Sea-salt $\cdot$ Size distribution $\cdot$ Dry deposition flux $\cdot$ New productivity 


\section{Introduction}

Size distribution of atmospheric particulate matter (PM) has been a concern of scientists for decades because it is closely related to the source and aerodynamic behavior and formation mechanisms. In general, the coarse particles (between 2.5 and $10 \mu \mathrm{m}$ ) are emitted directly into the atmosphere from natural sources such as sea-salt from bubble bursting and wind-blown crustal dust, whereas the fine particles $(<2.5 \mu \mathrm{m})$ are mainly from anthropogenic sources and secondary particles formed by gas-to-particle conversion processes (Senifeld and Pandis 2006). The fine- and coarse-mode particles concentrations are, however, essentially independent of each other. Both the particle size and chemical composition are crucial to evaluate their atmospheric lifetime, identify their major sources, understand their environmental and health effects, and quantify their radiative effects.

The major chemical compositions of PM include organic carbon, elemental carbon, water-soluble inorganic ions (WSIIs) and elements. Previous studies found that the proportion of WSIIs in $\mathrm{PM}_{2.5}$ varied between $20-77 \%$ and the secondary inorganic ions including $\mathrm{SO}_{4}{ }^{2-}, \mathrm{NO}_{3}{ }^{-}$and $\mathrm{NH}_{4}{ }^{+}$(SNA) constituted the majority of WSIIs (Huang et al. 2014; Wu et al. 2020). According to Senifeld and Pandis (2006), $\mathrm{Ca}^{2+}, \mathrm{Mg}^{2+}, \mathrm{Cl}^{-}$and $\mathrm{Na}^{+}$in the urban area are more abundant in the coarse mode particles, $\mathrm{SO}_{4}{ }^{2-}$ and $\mathrm{NH}_{4}{ }^{+}$are found to predominately in the fine mode, and $\mathrm{NO}_{3}{ }^{-}$exhibits a fine peak and a coarse peak depending on aerosol composition and environmental conditions. The mass fractions of SNA in fine particles have been found to increase significantly during haze episode and the size distribution peaks of $\mathrm{NO}_{3}{ }^{-}$and $\mathrm{SO}_{4}{ }^{2-}$ in the droplet mode also tended to move to a larger size (Huang et al. 2016; Tian et al. 2014; Wu et al. 2020). In Canad rural area, $\mathrm{NO}_{3}{ }^{-}$showed only one coarse mode peak at 4.0-7.0 $\mu \mathrm{m}$; furthermore, the mass median aerodynamic diameters of fine mode $\mathrm{NO}_{3}{ }^{-}(\sim 1 \mu \mathrm{m})$ at coastal sites were higher than at non-coastal sites $(0.38-0.66 \mu \mathrm{m})$ (Zhang et al. 2008). Similarily, the concentrations and size distributions of $\mathrm{NO}_{3}{ }^{-}$at a coastal site in Ningbo, a city in the Yangtz River Delta (YRD) region in China, showed obvious seasonal variations with a very minor peak in the size of $0.43-1.1 \mu \mathrm{m}$ and a dominant peak peak at 4.7-5.8 $\mu \mathrm{m}$ in summer (Zhang et al. 2018). In summer in the coastal region in the Pearl River Delta (PRD), South China, $26.6 \%$ of $\mathrm{NO}_{3}{ }^{-}$in $\mathrm{PM}_{10}$ could be attributable to sea-salt emissions because of the heterogeneous reaction of $\mathrm{HNO}_{3}$ on the surface of sea-salt particles while the portions decreased to less than $1 \%$ in the inland areas (Liu et al. 2015). However, at an inland site in the PRD region, $\mathrm{NO}_{3}{ }^{-}$showed unimodal size distributions with peak at $0.56-1.0 \mu \mathrm{m}$ in winter but bimodal ones in summer with peaks at 3.2-5.6 $\mu \mathrm{m}$ and 0.56-1 $\mu \mathrm{m}$ (Huang et al. 2020). In Beijing, the size distributions of $\mathrm{NO}_{3}{ }^{-}$were bimodal types for the four seasons, with a dominant peak in the size range of $0.43-1.1 \mu \mathrm{m}$ and a minor peak in the size range of 4.7-5.8 $\mu \mathrm{m}$ (Huang et al. 2016).

Apparently, the size distributions of WSIIs are strongly influenced by ambient temperature, geopraphical location, and air pollution level. Nevertheless, the size distributions of WSIIs have been investigated generally only during haze episodes, or representative months in two or four seasons (Zhang et al. 2008, 2018; Huang et al. 2016, 2020; Wu et al. 2019). The typical pollution characteristics and size distributions of WSIIs throughout the year have rarely been compared or analyzed comprehensively. The insufficient coverage of samples for the whole year may well contribute to the uncertainity of the nitrogen $(\mathrm{N})$ deposition flux, which is a function of size-dependent particle dry deposition velocity and size-segragated N species (Senifeld and Pandis 2006; Zhu et al. 2013; Qi et al. 2020). The size-dependent dry deposition velocity is a critical factor in estimating the deposition flux. Atmospheric deposition of reactive $\mathrm{N}$ may serve as an important external $\mathrm{N}$ supplier to the 
ecosystem and result in the change in the nutrient stoichiometry and contribute to ocean primary production and global $\mathrm{N}$ cycle (Srinivas et al. 2011; Taketani et al. 2018; Wu et al. 2019). In addition, the partition of gaseous $\mathrm{HNO}_{3}$ to sea-salt particles and crustal dusts would result in a spatially widespread deposition of the inorganic fixed $\mathrm{N}$ species to the open sea due to the relative lower deposition velocities of the aerosol species with respect to gaseous $\mathrm{HNO}_{3}$ and the higher $\mathrm{HNO}_{3}$ removal efficiency by precipitation (Spokes and Jickells 2005; Seinfeld and Pandis 2006; Zhu et al. 2013). The size-resolved measurements of $\mathrm{Na}^{+}, \mathrm{NH}_{4}{ }^{+}$, and $\mathrm{NO}_{3}{ }^{-}$from coastal stations and offshore islands would be of high value in validating the impacts of sea-salt particles on atmospheric $\mathrm{N}$ deposition (Neumann et al. 2016). In East Asian oceans, the coarse-mode nitrate produced via sea-salt surface heterogeneous reactions increased the total dry deposition amounts of reactive oxygenated nitrogen by a factor of two (Itahashi et al. 2016). In the western Taiwan Strait region, the contribution of nitrate associated with sea-salt to particulate inorganic $\mathrm{N}$ deposition was estimated to be 20.3-36.9\% (Wu et al. 2019).

Xiamen is an important port city in the west side of Taiwan Strait, China (Fig. 1). According to the Yearbook of Xiamen Special Economic Zone in 2019 (http://tjj.xm.gov. $\mathrm{cn} / \mathrm{tjzl} /$ ), Xiamen Port handled a total of 11.12 million TEU (twenty-foot equivalent unit) and ranked 7th in China and 14th in the world. In 2019, the possession of civil vehicles climbed to more than 16.6 million and the traffic jams are becoming a big problem in Xiamen. As a result, $\mathrm{NO}_{\mathrm{x}}$ emissions from ships and vehicles contribute to the nitrogen budget in the atmosphere. $\mathrm{NO}_{\mathrm{x}}$ reacts to $\mathrm{HNO}_{3}$ which condenses on wet particles to form nitrate. Particularly in Xiamen Bay with busy maritime activities and waving breaking, sea-salt emissions are considerably high and favor the formation of coarse mode particulate nitrogen compounds. Hence, coastal waters are expected to be impacted by atmospheric $\mathrm{N}$

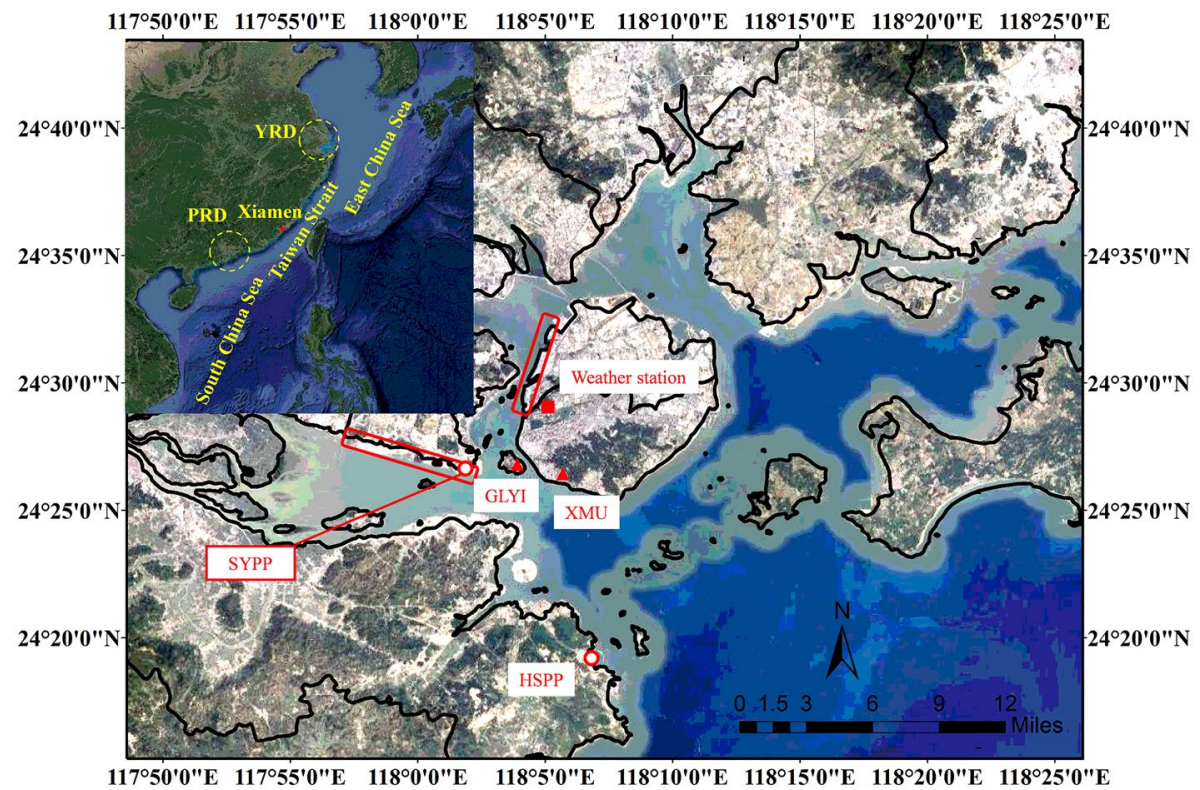

Fig. 1 Map of the sampling site (XMU), air quality monitoring site (GLYI), power plants and weather station in Xiamen Bay. The circle, solid square and rectangle represent the coal-fired power plant, weather station and dock area, respectively 
deposition (Wu et al. 2018, 2019). To better understand the development process of particle pollution and the effects of sea-salt on the dry deposition of particulate inorganic $\mathrm{N}$, the size-segregated aerosols were collected from March 2018 to June 2020 at an urban coastal site in Xiamen Bay. Seasonal variations and size distributions of WSIIs $\left(\mathrm{Cl}^{-}, \mathrm{NO}_{3}{ }^{-}, \mathrm{SO}_{4}{ }^{2-}\right.$, $\mathrm{Na}^{+}, \mathrm{NH}_{4}{ }^{+}, \mathrm{Mg}^{2+}, \mathrm{Ca}^{2+}$ and $\mathrm{K}^{+}$) as well as influencing factors and particulate $\mathrm{N}$ deposition were investigated in this study. This site is an ideal area to study the impact of sea-salt on air pollution and atmospheric $\mathrm{N}$ deposition into Xiamen Bay.

\section{Materials and methods}

\subsection{Collection of size-segregated particles}

A Micro-Orifice Uniform Deposition Impactor (MOUDI) sampler (Model M131, MSP Co., USA) with nominal cut sizes of $0.25,0.44,1.0,1.4,2.5,10$, and $16 \mu \mathrm{m}$ (inlet) was used to collect size-segregated samples. The sampler was located on the rooftop of a sixstory labs building on the campus of Xiamen University $\left(24.45^{\circ} \mathrm{N}, 118.08^{\circ} \mathrm{E}\right)$ and operated at a flow rate of $100 \mathrm{~L} \mathrm{~min}^{-1}$. The site is situated between two busy roads and about $2 \mathrm{~km}$ from the main shipping channel of Xiamen Port (Fig. 1). In addition, the site may also be affected two power plants, Songyu Power Plant (SYPP, $6.6 \mathrm{~km}$ to the west of XMU) and Houshi Power Plant (HSPP, $14.8 \mathrm{~km}$ to the south of XMU). Polycarbonate membrane (75 mm, PCTE-2.0, Tisch) and quartz filters $(90 \mathrm{~mm}$, Tissuquartz-2500QATUP, Pallflex) were used to collect particles $>0.25 \mu \mathrm{m}$ and $<0.25 \mu \mathrm{m}$, respectively. The quartz filters were pre-combustion at $600{ }^{\circ} \mathrm{C}$ for at least $4 \mathrm{~h}$ in a muffle furnace to remove organic impurities. All filters were individually kept in plastic Petri dishes and equilibrated in a desiccator for $48 \mathrm{~h}$ at a temperature of $20 \pm 5{ }^{\circ} \mathrm{C}$ and a relative humidity of $30 \pm 5 \%$ before and after sampling. Mass concentrations of size-segregated particles were obtained by gravimetry method with a microbalance (Sartorius BT $125 \mathrm{D}, \pm 0.01 \mathrm{mg}$ ). Sampling was performed from March 2018 to June 2020 excluding February 2019 due to the Spring Festival holiday. The sampling duration of individual samples was around $48 \mathrm{~h}$ at a frequency of 3-5 times a month. A total of 122 sets of MOUDI samples were routinely collected for water-soluble inorganic ions analysis: 36 for spring (March-May), 39 for summer (June-September), 20 for fall (October-November) and 27 for winter (December-February). The climate of Xiamen is sub-tropical and strongly influenced by the East Asian monsoon. The prevailing wind blows from the northeast in fall and winter and the southwest in summer. The highest average monthly temperature in Xiamen Island occurs in July $\left(28.6^{\circ} \mathrm{C}\right)$ and the lowest average monthly temperature occurs in February $\left(14.1^{\circ} \mathrm{C}\right)$. Precipitation is mainly concentrated in summer due to the typhoon. The average wind speed is higher in fall and winter than in summer and spring.

The daily average values of criteria air pollutants $\left(\mathrm{CO}, \mathrm{SO}_{2}, \mathrm{NO}_{2}, \mathrm{O}_{3}, \mathrm{PM}_{2.5}\right.$ and $\mathrm{PM}_{10}$ ) from an air quality monitoring site located in Gulangyu Island (GLYI, $2.5 \mathrm{~km}$ to the northwest of XMU) were obtained from the China National Urban Air Quality real-time Publishing Platform (http://106.37.208.233:20035/). Meteorological parameters including wind speed/direction (WS/WD), relative humidity $(\mathrm{RH})$, temperature $(\mathrm{T})$, pressure (P), visibility (Vis) and rainfall (RF) were from a weather station located in Xiamen Island (http://rp5.ru/archive.php?wmo_id=59134\&lang=cn), about $5.4 \mathrm{~km}$ to the north of XMU. The $\mathrm{PM}_{2.5}$ and $\mathrm{PM}_{10}$ concentrations derived from the MOUDI sampling system at XMU were comparable to the average values at GLYI using TEOM 
monitors during the same sampling period (Sect. S1 and Fig. S1). Both the local emission sources and different monitoring methods might contribute to the differences between the two sites.

\subsection{Chemical analysis}

A half of each filter was cut into a polypropylene centrifuge tube and ultrasonically extracted using $20 \mathrm{~mL}$ ultra-pure water for $30 \mathrm{~min}$. In order to prevent the loss of ammonium, ice was placed into the water tank to maintain a constant temperature. The extract was filtered through a hydrophilic PTFE syringe filter $(13 \mathrm{~mm} \times 0.22 \mu \mathrm{m})$. Then $5 \mathrm{~mL}$ ultra-pure water was added to the tube to rinse and filter again. The two extracts were then combined, resulting in a $25 \mathrm{~mL}$ solution. The cations $\left(\mathrm{Na}^{+}, \mathrm{NH}_{4}{ }^{+}, \mathrm{Mg}^{2+}, \mathrm{Ca}^{2+}\right.$ and $\left.\mathrm{K}^{+}\right)$and anions $\left(\mathrm{Cl}^{-}, \mathrm{NO}_{3}^{-}\right.$and $\left.\mathrm{SO}_{4}{ }^{2-}\right)$ were determined using an ion-chromatography system (PIC10, Qiangdao Puren Instruments Co., China) equipped with a conductivity detector. The details of the method and quality control data such as detection limits, recovery rates and analytical precision were previously reported (Wu et al. 2019).

\subsection{Dry deposition flux of particulate inorganic nitrogen}

The dry deposition flux $F_{d}\left(\mu \mathrm{g} \mathrm{N} \mathrm{m}{ }^{-2} \mathrm{~d}^{-1}\right)$ of inorganic nitrogen in size-segregated particles was calculated using the inferential method:

$$
F_{d}=\sum F_{d i}=\sum C_{i} \cdot V_{d i}
$$

Here, $V_{d i}$ and $C_{i}$ represent the dry deposition velocity $\left(\mathrm{cm} \mathrm{s}^{-1}\right)$ and concentration $(\mu \mathrm{g} \mathrm{N}$ $\mathrm{m}^{-3}$ ) of particulate inorganic nitrogen in size range $i$. The $V_{d i}$ is the size-dependent deposition velocity depending on weather conditions such as wind speed, humidity (hygroscopic growth) and air temperature as well as particle density and sea-surface roughness and was calculated by using the formula of Slinn (1982):

$$
V_{d i}=\frac{1}{R_{a}+R_{s i}}+V_{g i}
$$

where $R_{a}$ is the aerodynamic resistance; $R_{s i}$ and $V_{g i}$ are the surface resistance and the gravitational settling velocity for an individual interval $i$, respectively. More details regarding the parameterization of $R_{a}$, are shown in Sect. S2 and the calculation methods of $R_{s i}$ and $V_{g i}$ can be found in Zhang et al. (2001). Size-dependent particle dry deposition velocities (80\% $\mathrm{RH}$ and $25^{\circ} \mathrm{C}$ ) varied wind speed of $1-10 \mathrm{~m} \mathrm{~s}^{-1}$ (Fig. S2).

In previous studies, dry deposition fluxes on the surface ocean were estimated based on TSP, $\mathrm{PM}_{2.5}$ or $\mathrm{PM}_{10}$ measurements due to the lack of size distribution. The average deposition velocities of $0.1 \mathrm{~cm} \mathrm{~s}^{-1}$ for fine and $2 \mathrm{~cm} \mathrm{~s}^{-1}$ for coarse aerosols (Yeatman et al. 2001; Baker et al. 2003; Nakamura et al. 2005), $0.1-0.6 \mathrm{~cm} \mathrm{~s}^{-1}$ for $\mathrm{NH}_{4}^{+}$and $1.15-2 \mathrm{~cm} \mathrm{~s}^{-1}$ for $\mathrm{NO}_{3}^{-}$(Zhu et al. 2013; Qi et al. 2020) were assumed. Therefore, substantial errors would be associated with the estimation of deposition flux using a constant deposition velocity. In this study, we calculated the mass weighted dry deposition velocity of inorganic nitrogen species using the dry deposition velocities in the different size ranges and compared the values to the constant dry deposition velocities in the literatures. 


\section{Results and discussion}

\subsection{Mass size distribution of airborne particles}

The concentrations of total suspended particle (TSP) were calculated as the sum of the eight size classes of particles. The monthly mean values of TSP were rather variable during the study period and varied from $24.4 \mu \mathrm{g} \mathrm{m}^{-3}$ in June 2020 to $75.4 \mu \mathrm{g} \mathrm{m}^{-3}$ in April 2018 with an average of $45.2 \pm 21.3 \mu \mathrm{g} \mathrm{m}^{-3}$ (Fig. S3). The average concentration of $\mathrm{PM}_{10}, \mathrm{PM}_{2.5}$, and $\mathrm{PM}_{1}$ was $35.4 \pm 14.2 \mu \mathrm{g} \mathrm{m}^{-3}, 21.1 \pm 9.0 \mu \mathrm{g} \mathrm{m}^{-3}$, and $14.8 \pm 5.6 \mu \mathrm{g} \mathrm{m}^{-3}$, respectively. The variations of TSP concentrations were highly related to the cycle of the East Asian monsoon. The lowest mean values of TSP were typically found in summer when the clean air masses mainly came from the South China Sea and Taiwan Strait (Fig. S4). However, the northeasterly and northerly winds in spring, fall and winter were likely to bring air pollutants from upwind areas along the east coast and increase particle concentration.

The size distribution of particles can provide information about the origins of particles and the physical and chemical processes affecting particles as they are transported in the atmosphere (Huang et al. 2016). The measured size distributions of particles were bimodal during all seasons (Fig. S3b), with the dominant peak in the size range of 2.5$10 \mu \mathrm{m}\left(\mathrm{PM}_{2.5-10}\right)$ accounting for $33.5 \pm 4.7 \%$ of TSP and a minor peak in the range of $0.44-1 \mu \mathrm{m}\left(\mathrm{PM}_{0.44-1}\right)$ accounting of $16.1 \pm 4.2 \%$ of TSP in general. The size spectra of mass concentration were different from those observed in YRD urban agglomeration with peaks at $0.43-0.65 \mu \mathrm{m}$ (Wang et al. 2015) and Po Valley in Northern Italy with peaks at $1.0-1.8 \mu \mathrm{m}$ in winter and main peaks at 3.2-5.6 $\mu \mathrm{m}$ and sub-peaks at $0.32-0.56$ in summer (Canepari et al. 2019). Moreover, the concentration of $\mathrm{PM}_{2.5-10}$ displayed the order of fall $>$ spring $>$ winter $>$ summer, which was different from that of $\mathrm{PM}_{0.44-1}$ with a sequence of winter $>$ spring $>$ fall $>$ summer. Typically, coarse particles $(>2.5 \mu \mathrm{m})$ originate from natural and/or anthropogenic mechanical sources, while the fine particles $(<2.5 \mu \mathrm{m})$ are derived mainly from anthropogenic sources (Seinfeld and Pandis 2006). In Xiamen, there is little precipitation in fall and the weather is dry and windy and the average temperature is more than $20^{\circ} \mathrm{C}$ (Fig. S5). Increase in wind speed enhances sea-salt production and the wind-driven resuspension of fugitive dust (Prijith et al. 2014), of which a great part was coarse mode. However, there was no positive correlation between size-segregated PM and WS but significant negative correlations were found between RH and PM in the size range of $1.4-16 \mu \mathrm{m}$ (Table S1).

It is evident from Table $\mathrm{S} 1$ that, the relationship between gaseous pollutants $\left(\mathrm{SO}_{2}, \mathrm{NO}_{2}\right.$ and $\mathrm{CO}$ ) and $\mathrm{PM}$ with a diameter of less than $10 \mu \mathrm{m}$ were stronger than with $\mathrm{PM}_{>16}$ and $\mathrm{PM}_{10-16}$, indicating that a large part of $\mathrm{PM}_{10}$ and gaseous pollutants might come from the same sources such as fossil fuel combustion. In summer, the concentrations of $\mathrm{SO}_{2}$ and $\mathrm{NO}_{2}$ were lower than in winter due to the relatively rapid dispersion (Fig. S6), which could further limit the formation of secondary inorganic aerosols. In addition, their higher concentrations in winter in combination with lower T and WS (Fig. S5) might favor the gas-to-particle conversation and the accumulation of secondary aerosol. The correlations between $\mathrm{O}_{3}$ and size-segregated particles were not consistent, and there was no correlation between PM and RF. It seemed that the fine particles showed better correlations with T, P and Vis, while there was no consistent relationship between size-segregated PM and WS. Since atmospheric sulfate mainly exists in the condensation mode and droplet mode (Liu et al. 2017; Behera et al. 2015) and plays the most important role in decreasing visibility, $\mathrm{PM}_{0.44-1}$ and $\mathrm{PM}_{1-1.4}$ had the strongest correlations with visibility $(\mathrm{r}=-0.663$ and -0.575 , 
$\mathrm{p}<0.001)$. Although $\mathrm{PM}_{0.44-1}$ was significantly negatively correlated with WS $(\mathrm{r}=-0.275$, $\mathrm{p}<0.01$ ), there was no correlation between $\mathrm{PM}_{2.5-10}$ and WS. Therefore, the relative high concentrations of $\mathrm{PM}_{2.5-10}$ in fall were more related to low $\mathrm{RH}$ and air masses over the coastal region than with high wind speed. The seasonal characteristics of PM loading in the study area can be explained by the combined effects of natural and anthropogenic sources, meteorological parameters, and regional transboundary transport.

\subsection{Mass concentrations of water-soluble inorganic ions}

Our measurements of WSIIs over the study period varied between 5.1 and $35.0 \mu \mathrm{g} \mathrm{m}^{-3}$, with an average value of $13.2 \pm 6.1 \mu \mathrm{g} \mathrm{m}^{-3}$. The mass concentrations of WSIIs accounted for $16.9-49.9 \%$ of TSP mass with an average mean of $30.4 \pm 6.1 \%$. Among the eight species, sulfate, nitrate and ammonium were the most abundant ions, accounting for $30.7 \pm 6.8 \%, 29.1 \pm 8.6$, and $12.9 \pm 4.0 \%$ of the TWSIs, respectively. The concentrations of other ionic species followed the order of $\mathrm{Na}^{+}>\mathrm{Ca}^{2+}>\mathrm{Cl}^{-}>\mathrm{K}^{+}>\mathrm{Mg}^{2+}$ (Fig. S7a). However, the equivalent concentrations of $\mathrm{NH}_{4}{ }^{+}$were higher than that of $\mathrm{NO}_{3}{ }^{-}$and $\mathrm{SO}_{4}{ }^{-}$ (Fig. S7b), suggesting that $\mathrm{NH}_{4}{ }^{+}$played an important role in the acidity of PM. As can be seen from Fig. 2, WSIIs showed a very similar monthly pattern as that of TSP with much lower values in summer months and higher values in spring-winter months. There was a strong positive correlation between WSIIs and TSP ( $\mathrm{r}=0.886, \mathrm{p}<0.001,2$-tailed). As for $\mathrm{PM}_{>10}, \mathrm{PM}_{2.5-10}, \mathrm{PM}_{1-2.5}$ and $\mathrm{PM}_{1}$, the associated WSIIs (except $\mathrm{Ca}^{2+}$ in $\mathrm{PM}_{1}$ ) were also positively correlated with the particle loadings (Fig. S8, Table S2), suggesting that WSIIs played an important role in PM pollution. However, the fraction of WSIIs in PM were negatively correlated with PM mass concentration with the correlation coefficient between $-0.251(\mathrm{p}=0.005)$ for $\mathrm{PM}_{1}$ and $-0.483(\mathrm{p}<0.001)$ for $\mathrm{PM}_{2.5-10}$. In addition, the relative contribution of WSIIs to PM mass exhibited a general increasing tendency with decreasing particle size, ranging from $21.8 \pm 8.3 \%$ in $\mathrm{PM}_{>10}$ to $23.6 \pm 6.2 \%$ in $\mathrm{PM}_{2.5-10}, 30.7 \pm 9.5 \%$ in $\mathrm{PM}_{1-2.5}$, and $42.0 \pm 9.5 \%$ in $\mathrm{PM}_{1}$. This observation is consistent with the predominance of insoluble mineral dust in coarse particle observed in Beijing and YRD region (Huang

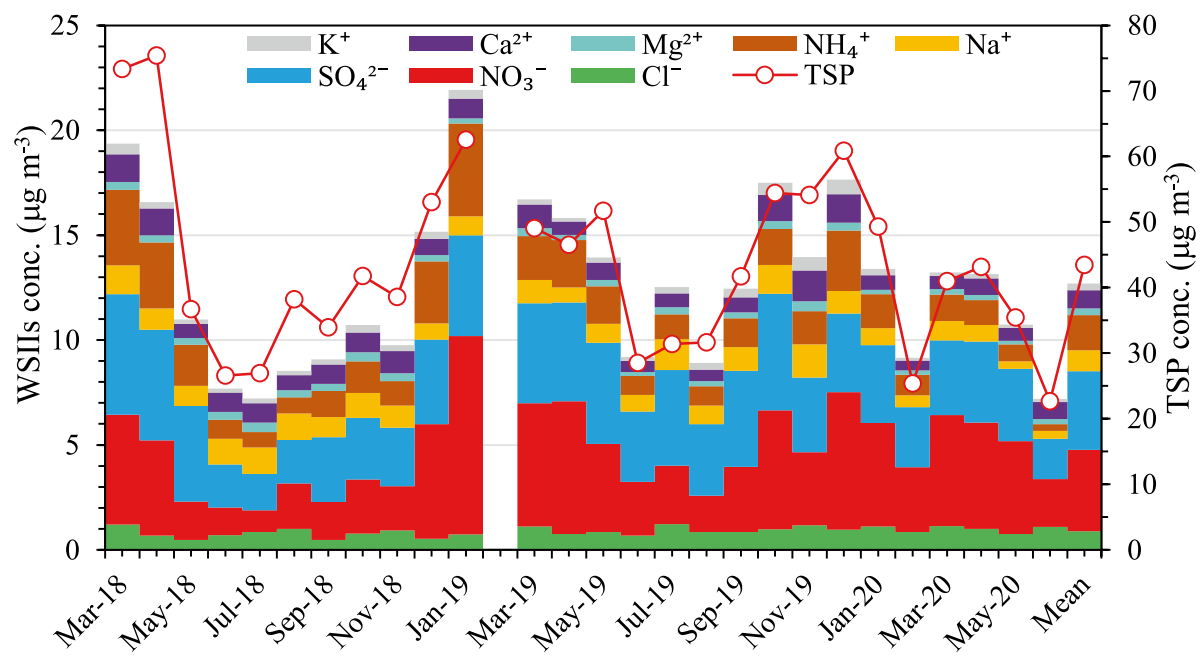

Fig. 2 Monthly profile of WSIIs in TSP at XMU between March 2018 and June 2020 
et al. 2016; Wang et al. 2015). The highest contribution of WSIIs to particle population was found in $\mathrm{PM}_{1}$ - likely related to the fact that secondary sulfate, nitrate and ammonium formation via homogeneous and heterogeneous transformation tend to accumulate in fine particles (Seinfeld and Pandis 2006).

From the monthly variations of WSIIs in Fig. 2, the temporal variations of $\mathrm{NH}_{4}{ }^{+}, \mathrm{NO}_{3}{ }^{-}$, $\mathrm{Ca}^{2+}$ and $\mathrm{K}^{+}$were more obvious than other ions, being higher in winter $\left(\mathrm{NH}_{4}{ }^{+}\right.$and $\left.\mathrm{NO}_{3}{ }^{-}\right)$ and fall $\left(\mathrm{Ca}^{2+}\right.$ and $\left.\mathrm{K}^{+}\right)$and lower in summer. The significant negative correlations between the above ionic species and $\mathrm{T}$ were detected while $\mathrm{SO}_{4}{ }^{2-}, \mathrm{Cl}^{-}, \mathrm{Na}^{+}$and $\mathrm{Mg}^{2+}$ were uncorrelated with $\mathrm{T}$ (Table S3), suggesting their different thermal stability and/or different emission sources. High temperature in summer (more than $28{ }^{\circ} \mathrm{C}$ ) (Fig. S5) was unfavorable for the formation of $\mathrm{NH}_{4} \mathrm{NO}_{3}$ through the homogeneous reaction between $\mathrm{NH}_{3}$ and $\mathrm{HNO}_{3}$; meanwhile more $\mathrm{K}^{+}$from biomass burning in fall and winter from north and east China could be transported to this site. The seasonality of $\mathrm{NH}_{4}{ }^{+}$and $\mathrm{NO}_{3}{ }^{-}$was similar to those reported in PRD and YRD (Yue et al. 2015; Wang et al. 2015), but different from the seasonal pattern in Beijing, which showed obvious high levels in summer (Huang et al. 2016; Li et al. 2013; Liu et al. 2017). In summer, Beijing is frequently influenced by the more polluted air masses from Heibei and Shandong provinces, and the humid climate is also favorable for the rapid formation of secondary inorganic aerosol. $\mathrm{Na}^{+}, \mathrm{Mg}^{2+}, \mathrm{Ca}^{2+}$ and $\mathrm{K}^{+}$ showed negative correlations with RH and RF, indicating that their fugitive dust sources might be subjected to the wash-out by rain and the reduced resuspension by wet weather. The significant positive correlation between $\mathrm{Ca}^{2+}$ and WS $(\mathrm{r}=0.289, \mathrm{p}<0.001)$ reinforced the contribution of wind-driven resuspension of fugitive dust to coarse $\mathrm{Ca}^{2+}$. Obvious seasonal changes of $\mathrm{Cl}^{-}$and $\mathrm{Na}^{+}$were not observed and both showed no correlation with wind speed. Thus, the variations of sea-salt was more influenced by the local waves breaking on the shore as the investigated site is very close to the seashore. However, $\mathrm{SO}_{4}{ }^{2-}$ and $\mathrm{NO}_{3}{ }^{-}$were more likely to accumulate in the atmosphere under low wind speed. It is noted that only SNA showed significant negative correlations with visibility, confirming the important role of ammonium sulfate and ammonium nitrate in visibility impairment (Wu et al. 2020; Cao et al. 2012). The three secondary ionic species were also often observed to increase rapidly under adverse weather conditions (Huang et al. 2014; Dai et al. 2018). The statistically significant correlations between WSIIs (except $\mathrm{Cl}^{-}$and $\mathrm{Na}^{+}$) and gaseous pollutants $\left(\mathrm{NO}_{2}\right.$ and $\left.\mathrm{SO}_{2}\right)$ were similar to those observed for PM in Table $\mathrm{S} 1$ because they were all strongly controlled by the seasonal shift in the temperature, the prevailing wind direction and the mixing layer height. These findings indicate that the formation of secondary water-soluble ions in fine particles might speed up under low T and WS and high gaseous precursors and particle loading. In fact, winter-spring witnessed the higher concentrations of $\mathrm{SO}_{2}$ and $\mathrm{NO}_{2}$ with respect to that in summer (Fig. S6). In this study, both PM and WSIIs concentrations in February 2020 were significant lower than in January and March 2020 due to the dramatic decrease in anthropogenic emissions during the Lunar New Year holiday and the COVID-19 pandemic lockdown.

Figure 3 presents the average mass concentrations of eight ionic species in different mass concentration ranges for $\mathrm{PM}_{1}, \mathrm{PM}_{1-2.5}, \mathrm{PM}_{2.5-10}$ and $\mathrm{PM}_{>10}$. The mass concentrations of ionic species showed increasing trends as the PM increased from low to high concentrations. However, the mass fraction of ionic species in PM declined when PM mass concentration increased. For the specific contribution of each ion to the total ionic species, the evolution patterns of the ionic species behaved differently between fine and coarse particles. The mass fraction of $\mathrm{NO}_{3}{ }^{-}$increased from $8 \%$ in the lowest level to $41 \%$ in the highest level for $\mathrm{PM}_{1}$, from 38 to $44 \%$ for $\mathrm{PM}_{1-2.5}$, from 32 to $51 \%$ for $\mathrm{PM}_{2.5-10}$, and from 31 to $47 \%$ for $\mathrm{PM}_{>10}$. The $\mathrm{SO}_{4}{ }^{2-}$ relative contribution decreased significantly in $\mathrm{PM}_{1}$, remained 

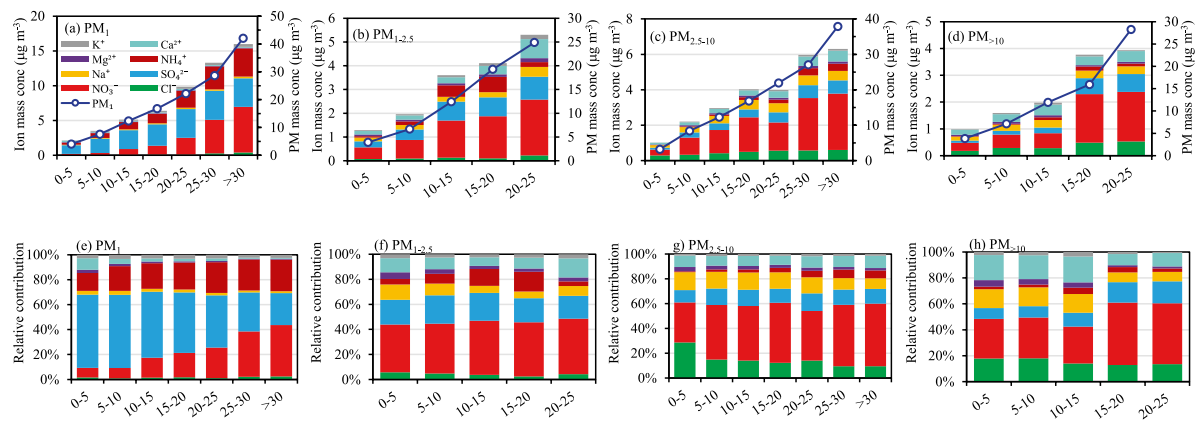

Fig. 3 Average concentrations of eight water-soluble inorganic ions (a-d) and relative mass contributions (e-h) in $\mathrm{PM}_{1}, \mathrm{PM}_{1-2.5}, \mathrm{PM}_{2.5-10}$ and $\mathrm{PM}_{>10}$ in different ranges

constant in $\mathrm{PM}_{1-2.5}$ and $\mathrm{PM}_{2.5-10}$, and increased slightly in $\mathrm{PM}_{>10}$ as the $\mathrm{PM}$ mass concentration increased. For $\mathrm{NH}_{4}^{+}$, the mass fraction increased slightly in $\mathrm{PM}_{1}$ and $\mathrm{PM}_{1-2.5}$ but remained constant in $\mathrm{PM}_{2.5-10}$ and $\mathrm{PM}_{>10}$ with $\mathrm{PM}$ mass concentration. This indicated that $\mathrm{NO}_{3}{ }^{-}$and $\mathrm{NH}_{4}{ }^{+}$formation seemed to be more sensitive to fine particle pollution than $\mathrm{SO}_{4}{ }^{2-}$ at the investigated site. Similar variations were also found in Xi'an and Beijing where annual $\mathrm{PM}_{2.5}$ levels have never attained the air environment quality level-2 standard in China (Dai et al. 2018; Tan et al. 2018). In coarse particles, the mass fractions of $\mathrm{Cl}^{-}$ and $\mathrm{Na}^{+}$displayed a trend of slight decrease with PM mass concentration, indicating that sea-salt might play a less decisive role at the coastal site on the incremental PM. For $\mathrm{Ca}^{2+}$, the mass fraction showed different evolution between fine and coarse mode particles, probably because it is mainly concentrated in the coarse mode.

\subsection{Size distribution of water-soluble inorganic nitrogen}

The average size distributions of WSIIs, $\mathrm{NH}_{4}{ }^{+}, \mathrm{NO}_{3}{ }^{-}$and other ions in different seasons are shown in Figs. 4 and S9. The distributions of WSIIs varied with the season, but generally exhibited obvious bimodal types, with a peak in the range of $0.25-0.44 \mu \mathrm{m}$ or $0.44-1 \mu \mathrm{m}$ in the fine mode and a peak in the range of 2.5-10 $\mu \mathrm{m}$ in the coarse mode. In spring and winter when the temperature is low, both $\mathrm{NH}_{4}{ }^{+}$and $\mathrm{NO}_{3}{ }^{-}$in $\mathrm{PM}_{0.44-1}$ (corresponding to the droplet mode) exhibited the most dramatic increase. As a result, the elevated concentration would lead to the size distribution peak of WSIIs in the fine mode $(0.25-0.44 \mu \mathrm{m}$ in fall and summer) shifting toward a larger size $(0.44-1 \mu \mathrm{m}$ in spring and winter). The tendency of $\mathrm{NH}_{4}{ }^{+}$and $\mathrm{NO}_{3}{ }^{-}$concentrations to peak at a slightly larger sizes in winter or during
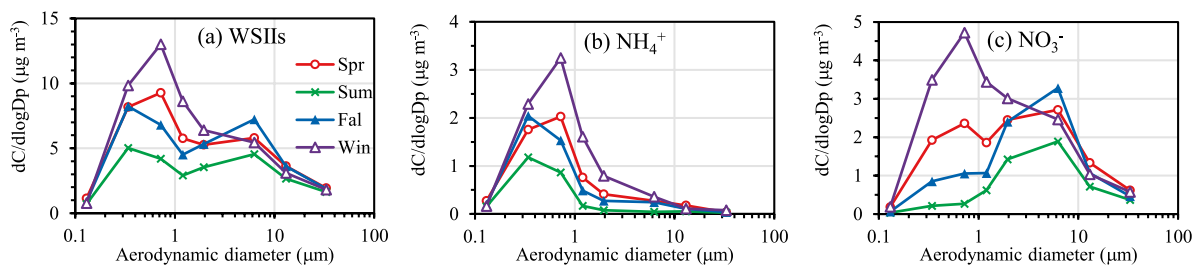

Fig. 4 Seasonal variations in the size distribution of the total (a) and individual water-soluble inorganic ions (b-c) 
pollution periods was also reported in Beijing, Shanghai and Canadian rural area (Huang et al. 2016; Tian et al. 2014; Zhang et al. 2008). Enhanced heterogeneous aqueous reaction and the hygroscopic growth of smaller particles at the high $\mathrm{RH}$ were suggested to be the main reasons. However, the values of RH in summer in Xiamen were not significantly different from those in spring (Fig. S5). Therefore, the formation of high droplet-mode $\mathrm{NH}_{4}{ }^{+}$ and $\mathrm{NO}_{3}{ }^{-}$might be favored under the combined effect of high $\mathrm{RH}$ and low T.

It was clear that $\mathrm{Na}^{+}$and $\mathrm{Cl}^{-}$were mainly associated with coarse particle, with a peak at 2.5-10 $\mu \mathrm{m}$ (Fig. S9a and b). One major source of $\mathrm{Na}^{+}$and $\mathrm{Cl}^{-}$in atmospheric coarse aerosol is sea-salt, in which $\mathrm{Na}^{+}$is closely related to $\mathrm{Cl}^{-}$(Table S2). In this study, the molar ratio of $\mathrm{Na}^{+}$to $\mathrm{Cl}^{-}$in $\mathrm{PM}_{2.5-10}$ varied from 0.85 to 2.31 with a median of 1.60 , which did not coincide with the characteristic seawater ratio for $\mathrm{Na}^{+} / \mathrm{Cl}^{-}$(approximately 0.89 ). Moreover, the level of $\mathrm{Cl}^{-}$observed in $\mathrm{PM}_{2.5-10}$ gave higher molar ratios in summer and fall than in spring and winter. This is thought to be due to the condensation of $\mathrm{HNO}_{3}$ and/or $\mathrm{N}_{2} \mathrm{O}_{5}$ oxidation on the surface of sea-salt aerosol to form $\mathrm{NaNO}_{3}\left(\mathrm{NaCl}+\mathrm{HNO}_{3}=\mathrm{NaNO}_{3}+\mathrm{HCl}\right.$, $\mathrm{N}_{2} \mathrm{O}_{5}+\mathrm{NaCl}=\mathrm{ClNO}_{2}+\mathrm{NaNO}_{3}$ ) (Yao and Zhang 2012). It is notable that a minor peak of $\mathrm{Cl}^{-}$was observed in the size range of $0.44-1 \mu \mathrm{m}$ in winter and spring, when $\mathrm{T}$ was low and strong northeasterly winds prevailed (Figs. S4 and S5). In urban Beijing, the size distributions of $\mathrm{Na}^{+}$and $\mathrm{Cl}^{-}$were both bimodal in the four seasons, peaking at $0.43-0.65 \mu \mathrm{m}$ and 4.7-5.8 $\mu \mathrm{m}$, probably due to the contribution of biomass burning and coal combustion (Li et al. 2013; Huang et al. 2016). Measurements of $\mathrm{Cl}^{-}$and $\mathrm{Na}^{+}$in PRD showed dominant peaks at $0.43-0.65 \mu \mathrm{m}$ in all seasons, with the highest level was found in winter for $\mathrm{Cl}^{-}$and in summer for $\mathrm{Na}^{+}$, indicating the important impact of anthropogenic sources and biomass burning (Wang et al. 2015). In this study, the correlation between $\mathrm{Na}^{+}$and $\mathrm{Cl}^{-}$in $\mathrm{PM}_{2.5-10}(\mathrm{r}=0.707, \mathrm{p}<0.001)$ was much stronger than that in $\mathrm{PM}_{1}(\mathrm{r}=0.413, \mathrm{p}<0.001)$ (Table S2). However, the concentrations of $\mathrm{Cl}^{-}$in the coarse mode were far higher than those in the fine mode. Thus, coal combustion emissions from the two nearby power plants to the south and west of the sampling site were not likely the source of $\mathrm{Cl}^{-}$in the fine mode. Other emissions from biomass burning and coal combustion to the north/northeast of the location as well as the reduction of $\mathrm{NH}_{4} \mathrm{Cl}$ volatilization loss at low temperature might contribute to the fine model $\mathrm{Cl}^{-}$in spring and winter. The significant correlation (at the $99.9 \%$ confidence level) between $\mathrm{Cl}^{-}$and $\mathrm{NH}_{4}{ }^{+}$was only found in $\mathrm{PM}_{1}(\mathrm{r}=0.365)$, indicating an important occurrence of $\mathrm{NH}_{4} \mathrm{Cl}$ in winter and spring. Nevertheless, the correlation between $\mathrm{Cl}^{-}$and $\mathrm{NO}_{3}{ }^{-}$was significant and positive in the four particle populations, with a stronger correlation in $\mathrm{PM}_{1}(\mathrm{r}=0.660, \mathrm{p}<0.001)$ than in other three particle populations $(\mathrm{r}=0.422-0.461, \mathrm{p}<0.001)$, suggesting that $\mathrm{NH}_{4} \mathrm{NO}_{3}$ was less volatile than $\mathrm{NH}_{4} \mathrm{Cl}$, as $\mathrm{HCl}$ is more volatile than $\mathrm{HNO}_{3}$.

The seasonal variations of the $\mathrm{SO}_{4}{ }^{2-}$ mass concentrations were similar to the seasonal patterns of $\mathrm{NH}_{4}{ }^{+}$and $\mathrm{K}^{+}$(Figs. 4 and S9). Furthermore, the three species showed similar unimodal distributions with a dominant peak at $0.25-0.44 \mu \mathrm{m}$ in summer and fall or $0.44-1 \mu \mathrm{m}$ in spring and winter, which was consistent with previous observation in YRD and PRD (Huang et al. 2016; Wang et al. 2015) but different from the bimodal distributions in the Jing-Jin-Ji urban areas ( $\mathrm{Li}$ et al. 2013). In general, fine mode $\mathrm{SO}_{4}{ }^{2-}$ is formed by the oxidation of $\mathrm{SO}_{2}$ through a slow homogeneous gas-phase oxidation and/or gas-to-particle (heterogeneous) oxidation. Thus, the main peak of sulfate falls in the fine mode. The fine mode $\mathrm{SO}_{4}{ }^{2-}, \mathrm{NH}_{4}{ }^{+}$and $\mathrm{K}^{+}$accounted for $85.2 \pm 7.0 \%$, $90.8 \pm 6.3 \%$ and $70.1 \pm 7.8 \%$ of their total mass, respectively, indicating the formation of $\mathrm{SO}_{4}{ }^{2-}$ and $\mathrm{NH}_{4}{ }^{+}$through in-cloud processes (Zhuang et al. 1999) and the potential ability of biomass burning aerosols serving as cloud condensation nuclei (Kaufman and Fraser 1997). In the present work, $\mathrm{NH}_{4}{ }^{+}$equivalent concentration in fine mode $(89 \pm 65$ 
neq $\left.\mathrm{m}^{-3}\right)$ was more than sufficient to neutralize $\mathrm{SO}_{4}{ }^{2-}\left(70 \pm 26 \mathrm{neq} \mathrm{m}^{-3}\right)$. Moreover, the excess $\mathrm{NH}_{4}{ }^{+}$concentration in unit of $\mu \mathrm{mol} \mathrm{m}{ }^{-3}$, calculated as $\left[\mathrm{NH}_{4}{ }^{+}\right]-1.5 \times\left[\mathrm{SO}_{4}{ }^{2-}\right]$ according to Pathak et al. (2009), showed significant correlation with nitrate concentration $(\mathrm{r}=0.828, \mathrm{p}<0.001)$, implying that $\mathrm{NH}_{4} \mathrm{HSO}_{4},\left(\mathrm{NH}_{4}\right)_{2} \mathrm{SO}_{4}$ and $\mathrm{NH}_{4} \mathrm{NO}_{3}$ might coexist in fine particles. Sulfate in coarse particles could be partly from the sea-salt and/ or the reactions of $\mathrm{SO}_{2}$ on the surface of sea-salt or soil particles (Zhuang et al. 1999). As shown in Table $\mathrm{S} 2$, for $\mathrm{SO}_{4}{ }^{2-}$ and $\mathrm{Na}^{+}$the correlation was statistical significant in coarse particles $\left(\mathrm{r}=0.329, \mathrm{p}<0.001\right.$ in $\mathrm{PM}_{2.5-10}$ and $\mathrm{r}=0.265, \mathrm{p}=0.003$ in $\left.\mathrm{PM}_{>10}\right)$ but the correlation between $\mathrm{SO}_{4}{ }^{2-}$ and $\mathrm{Ca}^{2+}$ was significant only in $\mathrm{PM}_{2.5-10}(\mathrm{r}=0.365$, $\mathrm{p}<0.001$ ) which supported the above speculation.

Different from $\mathrm{SO}_{4}{ }^{2-}$, the size distributions of $\mathrm{NO}_{3}{ }^{-}$were either bimodal with two peaks located in $2.5-10 \mu \mathrm{m}$ and $0.44-1 \mu \mathrm{m}$ in spring and winter or unimodal at $2.5-10 \mu \mathrm{m}$ in summer and fall (Fig. 4c). The coarse mode $\mathrm{NO}_{3}{ }^{-}$accounted for $18.8 \%$ $89.1 \%$ of the total nitrate with an average mean of $54.6 \pm 18.0 \%$. A dramatic decrease of fine mode $\mathrm{NO}_{3}{ }^{-}$was found in summer due to the high temperature $\left(28.0 \pm 1.3{ }^{\circ} \mathrm{C}\right)$ which are known to prevent formation of particulate $\mathrm{NH}_{4} \mathrm{NO}_{3}$ (Seinfeld and Pandis 2006). Similar bimodal distributions were also reported in Beijing for the four seasons, with a dominant peak in the size range of $0.43-1.1 \mu \mathrm{m}$ and a minor peak in the size range of 4.7-5.8 $\mu \mathrm{m}$ (Huang et al. 2016). In the urban area of Sheffield, $\mathrm{UK}, \mathrm{NO}_{3}{ }^{-}$exhibited a bimodal distribution when the air masses traveled long distances over the land but the fine mode $\mathrm{NO}_{3}{ }^{-}$was almost indiscernible when the air masses moved mostly over the sea (Xie et al. 2009). At a suburban area of Hong Kong in winter, $\mathrm{NO}_{3}{ }^{-}$was found mainly distributed in the coarse particles $(3.95 \pm 0.69 \mu \mathrm{m})$ attributing to the surface reactions of $\mathrm{HNO}_{3}$ gas with sea-salt or soil particles (Zhuang et al. 1999). However, at an inland site in the $\mathrm{PRD}$ region, $\mathrm{NO}_{3}{ }^{-}$displayed unimodal distributions (peaks at $0.56-1.0 \mu \mathrm{m}$ ) in winter but bimodal ones in summer (peaks at $3.2-5.6 \mu \mathrm{m}$ and $0.56-1 \mu \mathrm{m}$ ) (Huang et al. 2020). In this study, the size distributions of $\mathrm{NO}_{3}{ }^{-}$varied with the season indicating that $\mathrm{NO}_{3}{ }^{-}$might exist in different forms between the fine and coarse mode particles. $\mathrm{NO}_{3}{ }^{-}$in the fine mode could be neutralized by the excess $\mathrm{NH}_{4}{ }^{+}$ and were prone to exist in the form of $\mathrm{NH}_{4} \mathrm{NO}_{3}$, which is thermodynamically unstable. The average $\mathrm{NH}_{4}{ }^{+} / \mathrm{SO}_{4}{ }^{2-}$ molar ratio in $\mathrm{PM}_{1}$ during the warm (summer and fall) and cold (winter and spring) times were $1.51 \pm 0.42$ and $3.31 \pm 0.89$, respectively, indicating there was no extra $\mathrm{NH}_{4}{ }^{+}$to neutralize nitrate in the submicron mode particles in warm times. We can therefore assume that the residucal nitrate in $\mathrm{PM}_{1}$ in warm times may be combined with other cation ions instead of $\mathrm{NH}_{4}{ }^{+}$. However, no significant positive correlation among the concentrations of $\mathrm{NO}_{3}{ }^{-}, \mathrm{Na}^{+}, \mathrm{Ca}^{2+}, \mathrm{K}^{+}$, and $\mathrm{Mg}^{2+}$ in submicron mode particles was found in the warm seasons, indicating multiple chemical forms of nitrate in the submicron mode particles. In addition, the ratio of $\mathrm{NO}_{3}{ }^{-}$mass in $\mathrm{PM}_{0.44-1}$ to that in $\mathrm{PM}_{2.5-10}$ also exhibited an apparent negative correlation with temperature $(\mathrm{r}=-0.596, \mathrm{p}<0.001)$, but a positive correlation with excess $\mathrm{NH}_{4}{ }^{+}$in fine mode $(\mathrm{r}=0.622, \mathrm{p}<0.001)$. The negative correlation between the fraction of nitrate associated with submicron particles and temperature was also reported over the Atlantic Ocean (Morin et al. 2009). In the Jing-Jin-Ji urban agglomeration (China), significant higher concentrations of fine mode $\mathrm{NO}_{3}{ }^{-}$were also found in summer due to the humid condition and polluted air masses ( $\mathrm{Li}$ et al. 2013). In the urban Madrid (Spain), $\mathrm{NO}_{3}{ }^{-}$concentrations in $\mathrm{PM}_{2.5-10}$ in summer were higher than in winter due to various African dust outbreaks observed in summer while higher values of $\mathrm{NO}_{3}{ }^{-}$associated with fine particles $\left(\mathrm{PM}_{0.5}, \mathrm{PM}_{0.5-1}\right.$ and $\left.\mathrm{PM}_{1-2.5}\right)$ were found in winter as $\mathrm{NH}_{4} \mathrm{NO}_{3}$ was exclusively detected in winter (Mirante et al. 2014). Park et al. (2004) suggested that coarse-mode 
nitrates at Jeju Island (Korea) during the Asian dust periods were mainly produced by the reaction of $\mathrm{HNO}_{3}$ gas with basic soil particles. To sum up, the size distribution of $\mathrm{NO}_{3}{ }^{-}$strongly depends on aerosol composition and relevant ambient conditions (e.g. $\mathrm{T}$ and $\mathrm{RH}$ ).

The significant seasonal variations of fine mode $\mathrm{NO}_{3}{ }^{-}$were mainly controlled by the formation of $\mathrm{NH}_{4} \mathrm{NO}_{3}$. The $\mathrm{NH}_{4} \mathrm{NO}_{3}$ formation routes might involve either the gasphase reaction $\mathrm{NH}_{3}+\mathrm{HNO}_{3} \leftrightarrow \mathrm{NH}_{4} \mathrm{NO}_{3}$ or the heterogeneous reaction between $\mathrm{NH}_{3}$ and the aqueous-phase reaction products formed upon hydrolysis of $\mathrm{N}_{2} \mathrm{O}_{5}$ that could be present on the surface of the pre-existing moist particle under moist condition (Pathak et al. 2011). Despite high gas-phase $\mathrm{NH}_{3}$ and $\mathrm{HNO}_{3}$ are expected to occur in summer due to high $\mathrm{NH}_{3}$ volatilization and enhanced gas-phase oxidation of $\mathrm{NO}_{2}$ (Wu et al. 2018; Zhang et al. 2008), the formation routes of $\mathrm{NH}_{4} \mathrm{NO}_{3}$ are strongly limited under high temperature and low particle loading. However, both the homogeneous and heterogeneous reactions would become significant in spring and winter due to the low temperature, high humidity, and high particle loading. For coarse mode $\mathrm{NO}_{3}{ }^{-}, \mathrm{NaNO}_{3}$ and $\mathrm{Ca}\left(\mathrm{NO}_{3}\right)_{2}$ are more likely to occur via the reactive uptake of $\mathrm{HNO}_{3}$ vapor on pre-existing alkaline sea-salt or mineral dust in $\mathrm{NH}_{3}$-limited environments. As shown in Table $\mathrm{S} 2, \mathrm{NO}_{3}{ }^{-}$ showed significant correlation (at the $99.9 \%$ confidence level) with $\mathrm{Na}^{+}$in $\mathrm{PM}_{2.5-10}$ and $\mathrm{PM}_{>10}(\mathrm{r}=0.367-0.448)$ and $\mathrm{Ca}^{2+}$ only in $\mathrm{PM}_{2.5-10}(\mathrm{r}=0.614)$, which confirmed the speculation that $\mathrm{HNO}_{3}$ could react with $\mathrm{CaCO}_{3}$ in the coarse particles. Nevertheless, no correlation was found between $\mathrm{NO}_{3}{ }^{-}$and $\mathrm{Ca}^{2+}$ in $\mathrm{PM}_{>10}$, which could be due to the fast removal rate by dry deposition and by precipitation scavenging for particles in this size range.

$\mathrm{Mg}^{2+}$ and $\mathrm{Ca}^{2+}$ are generally from soil particles with a small component from sea-salt. Their size distribution types were different from those of $\mathrm{K}^{+}$that was mainly from biomass burning and $\mathrm{Na}^{+}$that originated from sea-salt particles (Fig. S9). Moreover, $\mathrm{Ca}^{2+}$, $\mathrm{Mg}^{2+}$ and $\mathrm{K}^{+}$were all strongly correlated with $\mathrm{Na}^{+}$in $\mathrm{PM}_{1}, \mathrm{PM}_{1-2.5}, \mathrm{PM}_{2.5-10}$ and $\mathrm{PM}_{>10}$ (Table S2). The correlation between $\mathrm{Mg}^{2+}$ and $\mathrm{Na}^{+}$seemed to be stronger than those between $\mathrm{Ca}^{2+}$ or $\mathrm{K}^{+}$and $\mathrm{Na}^{+}$, especially in the coarse particles. Therefore, the size distributions of $\mathrm{Mg}^{2+}$ and $\mathrm{Ca}^{2+}$ could be influenced by a mix of fugitive dust and sea-salt particles. The heterogeneous chemistry on dust and sea-salt particles might act as a source for some particulate species (Yao and Zhang 2012).

The mass concentration ratios of $\mathrm{SO}_{4}{ }^{2-} / \mathrm{Na}^{+}, \mathrm{Ca}^{2+} / \mathrm{Na}^{+}$, and $\mathrm{K}^{+} / \mathrm{Na}^{+}$in seawater were $0.252,0.037$ and 0.038 , respectively. If assuming all $\mathrm{Na}^{+}$was generated from sea-salt, the sea-salt contribution to $\mathrm{SO}_{4}{ }^{2-}, \mathrm{Ca}^{2+}$ and $\mathrm{K}^{+}$can be estimated. Thus, the mass of nonsea-salt (nss-) $\mathrm{SO}_{4}{ }^{2-}, \mathrm{Ca}^{2+}$ and $\mathrm{K}^{+}$were calculated using the following formulas (Nakamura et al. 2005):

$$
\begin{gathered}
n s s-\mathrm{SO}_{4}{ }^{2-}=\mathrm{SO}_{4}{ }^{2-}-0.252 \times \mathrm{Na}^{+} \\
n s s-\mathrm{Ca}^{2+}=\mathrm{Ca}^{2+}-0.037 \times N a^{+} \\
n s s-K^{+}=\mathrm{K}^{2+}-0.038 \times \mathrm{Na}^{+}
\end{gathered}
$$

Figure S10 shows the average size distributions of the relative contribution of nonsea-salt component to the total measured mass. On average, the non-sea-salt contribution of $\mathrm{SO}_{4}{ }^{2-}, \mathrm{Ca}^{2+}$ and $\mathrm{K}^{+}$were $78.8 \%, 95.5$, and $84.4 \%$, respectively. In addition, the relative contribution of nss- $\mathrm{SO}_{4}{ }^{2-}$ and $\mathrm{K}^{+}$obviously decreased with particle size while nss-Ca ${ }^{2+}$ remained relatively stable. 


\subsection{Dry deposition flux}

The calculated size-dependant particle $\mathrm{V}_{\mathrm{d}}$ values in Fig. $\mathrm{S} 2$ were strongly influenced by particle size and wind speed. The values of $\mathrm{V}_{\mathrm{d}}$ for particles around $10 \mu \mathrm{m}$ were more than two orders of magnitude greater than the ones calculated for particles in the size range of $0.44-1 \mu \mathrm{m}$. The large particles are expected to be rapidly removed from the atmosphere by dry deposition, which means that they mainly deposit in the coastal regions. On the other hand, fine particles have a longer atmospheric lifetime and can be transported to the remote ocean. Therefore, there must exist a gradient of inorganic nitrogen deposition flux from land to sea. For particles of submicrometer size, the higher the wind speed, the smaller aerodynamic resistance and the more roughness to the sea surface and therefore the greater $\mathrm{V}_{\mathrm{d}}$. For particles with diameter larger than $2 \mu \mathrm{m}$ where gravitational settling plays a predominant role, the dry deposition velocity remained almost entirely unaffected by wind speed.

Based on the size-segregated $\mathrm{V}_{\mathrm{d}}$ for particles and the size distributions of $\mathrm{NH}_{4}{ }^{+}$and $\mathrm{NO}_{3}{ }^{-}$mass concentrations, the mass-weighted dry deposition velocities for these two inorganic $\mathrm{N}$ species in Xiamen Bay were calculated. The averaged mass-weighted $\mathrm{V}_{\mathrm{d}}$ of $\mathrm{NH}_{4}{ }^{+}$and $\mathrm{NO}_{3}{ }^{-}$during the study period were $0.14 \pm 0.12$ and $0.67 \pm 0.29 \mathrm{~cm} \mathrm{~s}^{-1}$, respectively. The differences in weighted $\mathrm{V}_{\mathrm{d}}$ between $\mathrm{NH}_{4}{ }^{+}$and $\mathrm{NO}_{3}{ }^{-}$were mainly caused by their size distributions. As shown in Fig. $4, \mathrm{NH}_{4}{ }^{+}$was mainly observed in fine particles with an average percentage of $90.8 \%$, while $\mathrm{NO}_{3}{ }^{-}$showed a double peak size distribution, with $55.9 \%$ in the coarse mode and $44.1 \%$ in the fine mode. The higher distribution ratio of coarse mode $\mathrm{NO}_{3}{ }^{-}$leaded to higher $\mathrm{V}_{\mathrm{d}}$ than that of $\mathrm{NH}_{4}{ }^{+}$. Table $\mathrm{S} 4$ summarizes the $\mathrm{V}_{\mathrm{d}}$ values used for the dry deposition flux calculation over the marginal seas in the northwestern Pacific Ocean. The average weighted $\mathrm{V}_{\mathrm{d}}$ for $\mathrm{NH}_{4}{ }^{+}$in this study was comparable with most available values in the literature. For $\mathrm{NO}_{3}{ }^{-}$, it exhibited a greater annual $\mathrm{V}_{\mathrm{d}}$ value, which was lower than most of $\mathrm{V}_{\mathrm{d}}$ values in the literature. Based on the size distributions of inorganic $\mathrm{N}$ species, the overall weighted $\mathrm{V}_{\mathrm{d}}$ values of $\mathrm{NH}_{4}{ }^{+}$ and $\mathrm{NO}_{3}{ }^{-}$were calculated to be 0.21 and $0.43 \mathrm{~cm} \mathrm{~s}^{-1}$, respectively, during the dust storm periods, and 0.02 and $0.28 \mathrm{~cm} \mathrm{~s}^{-1}$ during the normal days over the Yellow Sea (Shi et al. 2013). The $\mathrm{V}_{\mathrm{d}}$ calculated indirectly using the ratio of the total dry deposition and the corresponding particulate $\mathrm{N}$ species concentrations was $0.17 \pm 0.11 \mathrm{~cm} \mathrm{~s}^{-1}$ for $\mathrm{NH}_{4}{ }^{+}$and $0.35 \pm 0.20 \mathrm{~cm} \mathrm{~s}^{-1}$ for $\mathrm{NO}_{3}{ }^{-}$in Jiaozhou Bay, North China (Xing et al. 2018). The constant $\mathrm{V}_{\mathrm{d}}$ values of $\mathrm{NO}_{3}{ }^{-}$in the literature were between 1-2 $\mathrm{cm} \mathrm{s}^{-1}$ which would overestimate the dry deposition flux of $\mathrm{NO}_{3}-\mathrm{N}$. For example, the dry deposition flux of $\mathrm{NO}_{3}-\mathrm{N}$ using constant $\mathrm{V}_{\mathrm{d}}$ was around 6-7 times of that using size dependent dry deposition velocity over sea surface in Yellow Sea and East China Sea (Zhu et al. 2013; Fu et al. 2018; Luo et al. 2016). On the other hand, the dry deposition flux of $\mathrm{NH}_{4}-\mathrm{N}$ might be underestimated by assuming a low constant dry deposition velocity of $0.1 \mathrm{~cm} \mathrm{~s}^{-1}$. Based on a regional air quality model system, the dry deposition flux of nitrate in the East China Sea between 17 March and 22 April 2014 was between the calculations using constant and size dependent velocities ( $\mathrm{Li}$ et al. 2018; Fu et al. 2018; Luo et al. 2016). Given that the $\mathrm{V}_{\mathrm{d}}$ of inorganic $\mathrm{N}$ species is affected by multiple factors such as the size distribution of mass concentration, wind speed, air temperature and $\mathrm{RH}$ and varies from time to time even within the same area, the dry deposition fluxes of $\mathrm{NH}_{4}-\mathrm{N}$ and $\mathrm{NO}_{3}-\mathrm{N}$ were calculated using their size-dependent dry deposition velocities.

A total of 122 daily dry deposition fluxes of inorganic $\mathrm{N}$ species were calculated using the size-dependent $\mathrm{V}_{\mathrm{d}}$ and the size-segregated mass concentrations during the 
sampling period. Then, the daily deposition fluxes in each month were averaged to obtain monthly dry deposition flux (Fig. 5). Although the concentrations of $\mathrm{NH}_{4}-\mathrm{N}$ (mean $97 \pm 73 \mathrm{nmol} \mathrm{N} \mathrm{m}{ }^{-3}$ ) were higher than $\mathrm{NO}_{3}-\mathrm{N}\left(\right.$ mean $\left.67 \pm 45 \mathrm{nmol} \mathrm{N} \mathrm{m}^{-3}\right)$, the dry deposition fluxes of $\mathrm{NO}_{3}-\mathrm{N}\left(35.77 \pm 24.49 \mu \mathrm{mol} \mathrm{N} \mathrm{m}{ }^{-2} \mathrm{~d}^{-1}\right)$ were much higher than $\mathrm{NH}_{4}-\mathrm{N}$ (mean $10.95 \pm 11.89 \mu \mathrm{mol} \mathrm{N} \mathrm{m} \mathrm{N}^{-2} \mathrm{~d}^{-1}$ ) at the coastal site. On average, $77.2 \pm 12.7 \%$ of the particulate inorganic $\mathrm{N}$ dry deposition was from $\mathrm{NO}_{3}-\mathrm{N}$ due to its larger deposition velocities. These values are slightly lower than the fraction of $86.7 \%$ observed in the coastal region of the western Taiwan Strait (Wu et al. 2019), $81 \%$ at a coastal site in the Sea of Japan (Park et al. 2019) and 85\% over the North Western Pacific Ocean (Taketani et al. 2018). Nevertheless, the concentrations of both $\mathrm{NH}_{4}-\mathrm{N}$ and $\mathrm{NO}_{3}-\mathrm{N}$ were significantly correlated with their dry deposition fluxes $(r=0.477-0.612, p<0.001,2$-tailed $)$ and the lowest dry deposition flux were found in summer. This verifies that atmospheric concentration is one of important factors determining the dry deposition flux. It is noted that the dry deposition flux of inorganic $\mathrm{N}$ species in January 2019 was relatively low in spite of the highest concentration (Fig. 5). The main reason for this is that the incremental mass concentrations of $\mathrm{NH}_{4}{ }^{+}$and $\mathrm{NO}_{3}{ }^{-}$were mainly concentrated in the submicrometer particles with much lower dry deposition velocities (Figs. 4 and S2). Regardless of the size distributions of $\mathrm{NH}_{4}{ }^{+}$and $\mathrm{NO}_{3}{ }^{-}$, almost all dry deposition of inorganic $\mathrm{N}$ species came from coarse particles $\left(>2.5 \mu \mathrm{m}\right.$ dimeter) which contributed $96 \pm 4 \% \mathrm{NH}_{4}-\mathrm{N}$ and $99 \pm 1 \% \mathrm{NO}_{3}-\mathrm{N}$. These values were close to those reported in the Taiwan Strait $(90.3-99.8 \%)(\mathrm{Wu}$ et al. 2019) and higher than the ratio at a coastal site in Qingdao (83.2\%) (Qi et al. 2013).

In this study, the average weighted $\mathrm{V}_{\mathrm{d}}$ values of 0.14 and $0.67 \mathrm{~cm} \mathrm{~s}^{-1}$ correspond to the modeled dry deposition velocities for particles around 4.7 and $10.2 \mu \mathrm{m}$, respectively, which represent absolutely coarse mode. From this point, the reaction of gaseous $\mathrm{NH}_{3}$ (already present in the atmosphere and/or produced in the dissociation of $\mathrm{NH}_{4} \mathrm{NO}_{3}$ ) with acidified coarse sea-salt particles could dramatically increase $\mathrm{NH}_{4}-\mathrm{N}$ dry deposition flux (Rosenfeld et al. 2002; Zhu et al. 2013; Qi et al. 2020). At the mid-Atlantic U.S. coast, the average deposition velocity of $\mathrm{HNO}_{3}\left(0.76 \mathrm{~cm} \mathrm{~s}^{-1}\right)$ was very close to the corresponding weighted deposition velocitiy for particulate $\mathrm{NO}_{3}{ }^{-}\left(0.74 \mathrm{~cm} \mathrm{~s}^{-1}\right)$ (Russell et al. 2003). Assuming the dry deposition velocity of $\mathrm{HNO}_{3}$ is $0.63 \mathrm{~cm} \mathrm{~s}^{-1}$ over the sea surface (Zhang et al. 2010), the reaction of $\mathrm{HNO}_{3}$ with coarse-mode sea-salt and mineral particles ( $>10 \mu \mathrm{m}$ diameter) can also increase the removal eficiency of particulate $\mathrm{NO}_{3}-\mathrm{N}$ via dry deposition. However, the average deposition velocities for total $\mathrm{NO}_{3}{ }^{-}$resulting from shifts in $\mathrm{HNO}_{3}$ phase partitioning will not change significantly. If the chlorine depletion (calculated as $1.18 \times\left[\mathrm{Na}^{+}\right]-\left[\mathrm{Cl}^{-}\right]$in $\mu \mathrm{mol} \mathrm{m}{ }^{-3}$ ) and $\mathrm{NH}_{4}{ }^{+}$in the coarse-mode particles were entirely due to the above heterogeneous reactions on the surface of sea-salt particles, the
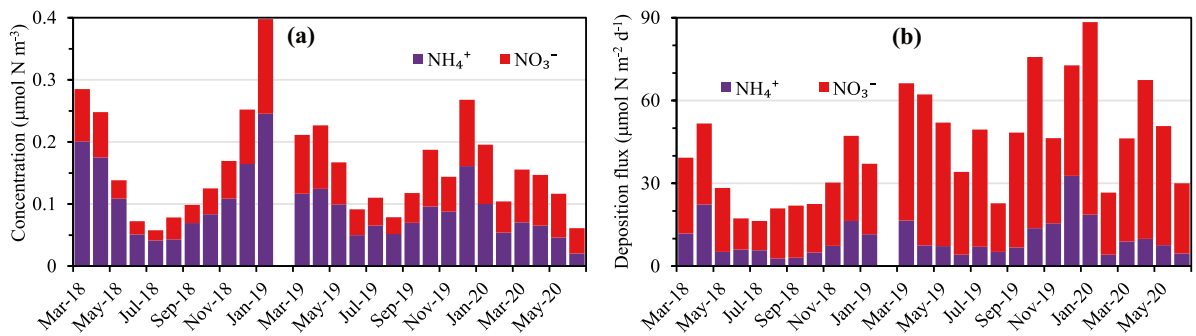

Fig. 5 Monthly variations in concentrations (a) and dry deposition fluxes (b) of particulate inorganic $\mathrm{N}$ in Xiamen Bay from March 2018 to June 2020 
contributions of sea-salt particles to the atmospheric $\mathrm{N}$ dry deposition were estimated to be $23.9-52.8 \%$ with an average of $34.0 \pm 10.2 \%$. Based on an air quality model system, the sea-salt related $\mathrm{NO}_{3}{ }^{-}$contributed $9 \%$ on average to the total particulate inorganic $\mathrm{N}$ deposition in the western Pacific Ocean with maximum contribution of $20 \%$ in the North Pacific ( $\mathrm{Li}$ et al. 2018). By using the CMAQ model containing the heterogeneous reactions between nitrogen-containing gases $\left(\mathrm{NO}_{2}, \mathrm{~N}_{2} \mathrm{O}_{5}\right.$ and $\left.\mathrm{HNO}_{3}\right)$ and sea-salt, the dry deposition flux of coarse-mode $\mathrm{NO}_{3}{ }^{-}$increased by $27.6-52.4 \%$ over the China seas (Xue et al. 2020), and the contribution of sea-salt particles to the atmospheric $\mathrm{N}$ deposition into the North Sea was approximately 3-7\% (Neumann et al. 2016). During 2002-2004, the reaction between $\mathrm{HNO}_{3}$ and sea-salt particles accounted for $31.8 \%$ and $51.2 \%$ of the total reactive oxygenated nitrogen deposition flux into Yellow Sea and East China Sea, respectively (Itahashi et al. 2016). These results suggest that the heterogeneous reactions between nitrogen-containing gases and sea-salt particles can significantly increase particulate $\mathrm{N}$ dry deposition over the ocean surface.

Compared to other coastal regions, the annual dry deposition fluxes of $\mathrm{NH}_{4}-\mathrm{N}$ $\left(4.00 \pm 4.34 \mathrm{mmol} \mathrm{N} \mathrm{m}^{-2} \mathrm{yr}^{-1}\right)$ and $\mathrm{NO}_{3}-\mathrm{N}\left(13.05 \pm 8.94 \mathrm{mmol} \mathrm{N} \mathrm{m}^{-2} \mathrm{yr}^{-1}\right)$ at our monitoring site were comparable to the calculations at the five coastal sites of the western Taiwan Strait (Wu et al. 2019), a coastal site of the Yellow Sea (Qi et al. 2013), margina catchment area in Singapore (He et al. 2011) and islands in the East China Sea (Zhu et al. 2013), but lower than the calculations at the coastal sites of the Sea of Japan (Kang et al. 2010; Park et al. 2019) and the actual measurements using settling buckets at a coastal site of the Yellow Sea (Xing et al. 2018) and a background site in the Pearl River estuary of the South China Sea (Yu et al. 2020) (Table S4). Also note that several studies in Table S4 showed comparative or higher $\mathrm{NH}_{4}-\mathrm{N}$ dry deposition fluxes than $\mathrm{NO}_{3}-\mathrm{N}$, probably due to the much higher concentrations of $\mathrm{NH}_{4}{ }^{+}$(Xing et al. 2018; Yu et al. 2019; Shi et al. 2013; Qi et al. 2020). This suggests that the direct comparison between our estimates with other regions is a very complex process because of the differences in study period/season, region, sampling method (TSP or size-segregated samples) and flux calculation method.

\subsection{Impact of atmospheric deposition on marine productivity}

Many studies have shown that the atmospheric deposition of nutrients to the sea surface have the potential to influence the marine ecosystem. For example, the nutrients and Asian dust addition incubation experiments carried out during a marine research $\mathrm{R} / \mathrm{V}$ cruise in Yellow Sea and East China Sea confirmed that both the concentration of chlorophyll-a (Chl- $a$ ) and the conversion efficiency index of $\mathrm{N}$ into Chl- $a$ showed a greater increase in contrast to the control (Liu et al. 2013). In the South China Sea, the enhancement of seawater Chl- $a$ was proven to be associated with the atmospheric $\mathrm{N}$ deposition (Kim et al. 2014). In the North Western Pacific Ocean, the annual average concentration of Chl- $a$ at the surface seawater increased from 0.04 to $0.10 \mathrm{mg} \mathrm{m}^{-3}$ and the gross primary productivity (interegated over sea depths of 0-200 m) increased from 85 to $147 \mathrm{mgC} \mathrm{m}^{-2} \mathrm{~d}^{-1}$ due to the input of the atmospheric inorganc $\mathrm{N}$ species by using an ecosystem model combined with a WRF-CMAQ model (Taketani et al. 2018). In the present study, the dry deposition of particulate inorganic $\mathrm{N}$ into Xiamen Bay is compared with other inputs of nitrogen. In 2017, the direct terrestrial influx of inorganic $\mathrm{N}$ to Xiamen Bay was 41,531 tons, including 38,400 tons from Jiulong River, 2362 tons from streamlet and 769 tons from sewage drain-off according to the 2017 Bulletin of Xiamen Marine Environmental Status (http://hyj.xm.gov.cn/lszt/hyhjxx/201806/ 
P020180621585654507979.pdf). Assuming that the composition of near-surface air at the coastal site was the same as that over nearshore waters (Russell et al. 2003), the annual dry deposition of $\mathrm{NO}_{3}-\mathrm{N}$ plus $\mathrm{NH}_{4}-\mathrm{N}$ into the Xiamen Bay was estimated to be 396.07 tons based on the water surface area $\left(1659 \mathrm{~km}^{2}\right)$ and the daily dry deposition flux. This value is approximately $0.95 \%$ of the terrestrial inorganic $\mathrm{N}$ inputs. It is noted that this value might be overestimated due to the decline trend from the sampling site to the inner bay. Further research must be conducted to set up more sampling sites in and around Xiamen Bay to reduce the uncertainity in atmospheric inorganic $\mathrm{N}$ deposition flux estimates.

The potential impact of atmospheric deposition of particulate inorganic $\mathrm{N}$ on the marine ecosystem in Xiamen Bay can be assessed by estimating the potential new primary production. Assuming that all of the particulate inorganic N deposited into Xiamen Bay are bioavailable to phytoplanton, the atmospheric input can be converted to carbon uptake based on the C:N ratio of 6.625 in the Redfield ratio in the ocean (De Leeuw et al. 2003; Zhang et al. 2010; Xing et al. 2018; Park et al. 2019). This ratio indicates that for every mole of nitrogen used, $6.625 \mathrm{~mol}$ of carbon is assimilated. By using dry deposition flux for inorganic $\mathrm{N}$ and the Redfield C:N ratio, the dry deposition of particulate inorganic $\mathrm{N}$ would then create a new productivity of $3.55 \mathrm{mgC} \mathrm{m}^{-2} \mathrm{~d}^{-1}$ on average with the highest in winter ( $\left.4.10 \mathrm{mgC} \mathrm{m}^{-2} \mathrm{~d}^{-1}\right)$ and the lowest in summer $\left(2.31 \mathrm{mgC} \mathrm{m}^{-2} \mathrm{~d}^{-1}\right)$ in the surface waters. According to the previous study in Xiamen Bay, the primary productivity was measured to be 92.1-233.1 mgC m${ }^{-2} \mathrm{~d}^{-1}$ ( $\mathrm{Li}$ et al. 1999). Based on this figure, the input of the external nitrogen supply contributes $1.3-4.7 \%$ (mean $2.2 \%$ ) of the primary productivity in Xiamen Bay. These ratios are close to $1.1-3.9 \%$ in the eastern China seas and $0.3-6.7 \%$ (mean $2.3 \%$ ) in the coastal region of Yellow Sea due to dry and wet deposition of inorganic $\mathrm{N}$ (Zhang et al. 2010; Qi et al. 2013) and higher than 0.08-1.6\% (mean 0.4\%) in the coastal region of the Sea of Japan due to dry deposition of particulate inorganic and organic $\mathrm{N}$ (Park et al. 2019).

It should be kept in mind that $\mathrm{NH}_{3}$ and $\mathrm{HNO}_{3}$ as well as particulate organic $\mathrm{N}$, which can form a substantial contribution to the $\mathrm{N}$ deposition (Zhang et al. 2010; Xing et al. 2018; Wu et al. 2018; Park et al. 2019), were not measured in this study. The dry deposition flux of particulate inorganic $\mathrm{N}$ reported in this study should be considered as a lower limit on the total dry deposition flux to Xiamen Bay. Hence, the real deposition flux of $\mathrm{N}$ to the surface waters would have a greater impact on marine biogeochemistry. In the western Baltic Sea, the contribution of shipping sector to the total $\mathrm{N}$ concentration in the sea water was up to $5 \%$ and the absolute shipping-related total $\mathrm{N}$ concentrations were found to be generally higher in the coastal regions by applying a coupled marine physical biogeochemical model (Neumann et al. 2020). Based on the simulation results using WRF-CMAQ in China seas, Chen et al. (2020) reported that the largest ship contribution to dry $\mathrm{N}$ deposition was generally along the shoreline and the western Taiwan Strait, which correspond to the shipping routes. Given that atmospheric emissions of nitrogen compounds from vehicles and marine vessels are continuing to increase in and around the Xiamen Bay as well as other port cities in China, an increasing importance of atmospheric nitrogen deposition on the coastal marine ecosystem can be expected. In addition, sea-salt emissions in the vicinity of the shoreline can help produce coarse-mode nitrate and then enhance shipping and vehicle related nitrogen deposition in the coastal regions. Therefore, careful considerations of the contributions of these gas-phase $\mathrm{N}$ species to the dry deposition, as well as organic $\mathrm{N}$, must be incorporated into future atmospheric $\mathrm{N}$ measurements. Besides, further studies such as stable $\mathrm{N}$ isotopic measurement for source partitioning and emission inventory compilation are needed to set emissions reduction policy. 


\section{Conclusions}

In this study, the size distributions of water-soluble inorganic ions in aerosol particles were measured to characterize the seasonal variations and the dry deposition of inorganic N in Xiamen Bay from March 2018 to June 2020. The results showed that the mass size distributions of aerosol were bimodal, peaking at $0.44-1.0 \mu \mathrm{m}$ and 2.5-10 $\mu \mathrm{m}$, and displayed obvious seasonal fluctuation due to changes in source emissions and local meteorological conditions. In addition, fine particles showed better correlations with temperature, pressure, and visibility than wind speed. Secondary ions $\left(\mathrm{SO}_{4}{ }^{2-}, \mathrm{NO}_{3}{ }^{-}\right.$and $\left.\mathrm{NH}_{4}{ }^{+}\right)$accounted for the major part of WSIIs, with a slightly higher fraction in the cold seasons $(78.7 \%)$ than in the warm seasons $(65.3 \%)$, while other ionic species followed the order of $\mathrm{Na}^{+}>\mathrm{Ca}^{2+}>\mathrm{Cl}^{-}>\mathrm{K}^{+}>\mathrm{Mg}^{2+}$. The average ratio of $\mathrm{NO}_{3}{ }^{-}$to $\mathrm{SO}_{4}{ }^{2-}$ exceeded 1.0, suggesting that emissions from mobile sources in Xiamen play a more important role in aerosol pollution than stationary source emissions. The mass concentrations of WSIIs in particle populations $\left(\mathrm{PM}_{1}, \mathrm{PM}_{1-2.5}, \mathrm{PM}_{2.5-10}\right.$, and $\mathrm{PM}_{>10}$ ) were all significantly correlated with PM mass but its contribution to PM mass displayed a decreasing trend with particle size, accounting for more than $40 \%$ in $\mathrm{PM}_{1}$, approximately twice that in $\mathrm{PM}_{>10}$.

The size distributions of WSIIs varied with the season, but generally exhibited similar bimodal types as that of aerosol particles. Both $\mathrm{Na}^{+}$and $\mathrm{Cl}^{-}$had a main peak at 2.5-10 $\mu \mathrm{m}$, which correspond well to the peak of $\mathrm{NO}_{3}{ }^{-}$in the coarse mode. Moreover, the average ratio of $\mathrm{Na}^{+} / \mathrm{Cl}^{-}$in $\mathrm{PM}_{2.5-10}$ was much higher than that in seawater, clearly confirming the heterogeneous reaction on the surface of sea-salt particles. The size distributions of $\mathrm{NH}_{4}{ }^{+}$and $\mathrm{SO}_{4}{ }^{2-}$ were very similar and their dominant peak moved from $0.25-0.44 \mu \mathrm{m}$ in summer and fall to $0.44-1 \mu \mathrm{m}$ in spring and winter due to the enhanced gas-phase oxidation and/or gas-to-particle oxidation. The fine mode peak of $\mathrm{NO}_{3}{ }^{-}$at $0.44-1 \mu \mathrm{m}$ became progressively less obvious with increasing temperature mainly due to the evaporation of $\mathrm{NH}_{4} \mathrm{NO}_{3}$ while the coarse mode peak at 2.5-10 $\mu \mathrm{m}$ remained stable because $\mathrm{NO}_{3}{ }^{-}$combined with $\mathrm{Na}^{+}$and $\mathrm{Ca}^{2+}$.

Although the average concentration of $\mathrm{NH}_{4}-\mathrm{N}$ was about 1.5 times of $\mathrm{NO}_{3}-\mathrm{N}$, the dry deposition flux of $\mathrm{NO}_{3}-\mathrm{N}$ was 3.3 times of $\mathrm{NH}_{4}-\mathrm{N}$ due to their very different size distribution. The contribution of sea-salt particles to atmospheric $\mathrm{N}$ dry deposition was estimated to be $24-53 \%$, assuming the chlorine depletion and $\mathrm{NH}_{4}{ }^{+}$in the coarse-mode particles were entirely associated with the heterogeneous reactions on the surface of sea-salt particles. The assumption may overestimate the impact of sea-salt particles because part of $\mathrm{NH}_{3}$ and $\mathrm{HNO}_{3}$ could also condense on the surface of acidified mineral dust. The mass weighted dry deposition velocities of $\mathrm{NH}_{4}-\mathrm{N}$ and $\mathrm{NO}_{3}-\mathrm{N}$ in Xiamen Bay were $0.14 \pm 0.12$ and $0.67 \pm 0.29 \mathrm{~cm} \mathrm{~s}^{-1}$, respectively, which were different from the literature values of $\mathrm{V}_{\mathrm{d}}$ over the marginal seas in northwestern Pacific Ocean. These differences indicate that it is hard to directly compare our results with other regions due to the different calculation method.

The dry deposition of particulate inorganic $\mathrm{N}$ accounted for less than $1 \%$ of other terrestrial $\mathrm{N}$ influxes into Xiamen Bay and could support $1.3-4.7 \%$ of the primary productivity. Taking into account other reactive $\mathrm{N}$ in the atmosphere and increasing anthropogenic emissions of $\mathrm{NO}_{\mathrm{x}}$, the atmospheric $\mathrm{N}$ input is a non-negligible external source to the ocean surface layer and could have a significant influence on biogeochemical cycles. To improve our understanding of the air-sea deposition fluxes of nutrients, further studies are required to include dry and wet deposition as well as $\mathrm{NO}_{\mathrm{x}}$ source apportionment. 
It is therefore necessary to take the air-sea deposition fluxes of nutrients into account in the integrated nutrient management scheme in coastal and offshore waters.

Supplementary Information The online version contains supplementary material available at https://doi. org/10.1007/s10874-021-09427-8.

Authors' contributions Shui-Ping Wu: Conceptualization, methodology, original draft preparation. Xiang Li: Original draft preparation. Yang Gao: Methodology, formal analysis and investigation. Mei-Jun Cai: Methodology, formal analysis and investigation. Chao Xu: Methodology, formal analysis and investigation. James J Schwab: Review and editing. Chung-Shin Yuan: Review and editing.

Funding This work was supported by the National Key Research and Development Program of China (2016YFC0502901), the National Natural Science Foundation of China (No. 41471390), and the Natural Science Foundation of Fujian Province of China (No.2017J01079).

Data availability The dataset used and/or analyzed in this study are available from the corresponding author on reasonable request.

\section{Declarations}

Ethics approval and consent to participate Not applicable.

Consent for publication Not applicable.

Competing interests The authors have no conflicts of interest to declare that are relevant to the content of this article.

\section{References}

Baker, A.R., Kelly, S.D., Biswas, K.F., Witt, M., Jickells, T.D.: Atmospheric deposition of nutrients to the Atlantic Ocean. Geophys. Res. Lett. 30, 2296-2299 (2003). https://doi.org/10.1029/2003GL018518

Behera, S., Cheng, J., Huang, X., Zhu, Q., Liu, P., Balasubramanian, R.: Chemical composition and acidity of size-fractionated inorganic aerosols of 2013-14 winter haze in Shanghai and associated health risk of toxic elements. Atmos. Environ. 122, 259-271 (2015). https://doi.org/10.1016/j.atmosenv.2015.09. 053

Canepari, S., Astolfi, M.L., Catrambone, M., Frasca, D., Marcoccia, M., Marcovecchio, F., Massimi, L., Rantica, E., Perrino, C.: A combined chemical/size fractionation approach to study winter/summer variations, ageing and source strngth of atmospheric particles. Environ. Pollut. 253, 19-28 (2019). https://doi.org/10.1016/j.envpol.2019.06.116

Cao, J.J., Wang, Q.Y., Chow, J.C., Watson, J.G., Tie, X.X., Shen, Z.X., Wang, P., An, Z.S.: Impacts of aerosol compositions on visibility impairment in Xi'an, China. Atmos. Environ. 59, 559-566 (2012). https://doi.org/10.1016/j.atmosenv.2012.05.036

Chen, D., Fu, X., Guo, X., Lang, J., Zhou, Y., Li, Y., Liu, B., Wang, W.: The impact of ship emissions on nitrogen and sulfur deposition in China. Sci. Total Environ. 708, 134636 (2020). https://doi.org/10. 1016/j.scitotenv.2019.134636

Dai, Q., Bi, X., Liu, B., Li, L., Ding, J., Song, W., Bi, S., Schulze, B.C., Song, C., Wu, J., Zhang, Y., Feng, Y., Hopke, P.K.: Chemical nature of $\mathrm{PM}_{2.5}$ and $\mathrm{PM}_{10}$ in Xi' an, China: insight into primary emissions and secondary particle formation. Environ. Pollut. 240, 155-166 (2018). https://doi.org/10.1016/j. envpol.2018.04.111

De Leeuw, G., Spokes, L., Jickells, T., Skjøth, C.A., Hertel, O., Vignati, E., Tamm, S., Schulz, M., Sørensen, L.-L., Pedersen, B., Klein, L., Schlunzen, K.H.: Atmospheric nitrogen inputs into the North Sea: effects on producitivity. Cont. Shelf Res. 23, 1743-1755 (2003). https://doi.org/10.1016/j.csr. 2003.06.011

Fu, J., Wang, B., Chen, Y., Ma, Q.: The influence of continental air masses on the aerosols and nutrients deposition over the western North Pacific. Atmos. Environ. 172, 1-11 (2018). https://doi.org/10. 1016/j.atmosenv.2017.10.041 
He, J., Balasubramanian, B., Burger, D.F., Hicks, K., Kuylenstierna, J.C.I., Palani, S.: Dry and wet atmospheric deposition of nitrogen and phosphorus in Singapore. Atmos. Environ. 45, 2760-2768 (2011). https://doi.org/10.1016/j.atmosenv.2011.02.036

Huang, B., Gan, T., Pei, C., Li, M., Cheng, P., Chen, D., Cai, R., Wang, Y., Li, L., Huang, Z., Gao, W., $\mathrm{Fu}, \mathrm{Z}$., Zhou, Z.: Size-segregated characteristics and formation mechanisms of water-soluble inorganic ions during different seasons in Heshan of Guangdong. China. Aerosol Air Qual. Res. 20, 1961-1973 (2020). https://doi.org/10.4209/aaqr.2019.11.0582

Huang, X., Liu, Z., Zhang, J., Wen, T., Ji, D., Wang, Y.: Seasonal variation and secondary formation of sizesegregated aerosol water-soluble inorganic ions during pollution episodes in Beijing. Atmos. Res. 168, 70-79 (2016). https://doi.org/10.1016/j.atmosres.2015.08.021

Huang, R.J., Zhang, Y., Bozzetti, C., Ho, K.F., Cao, J.J., Han, Y., Daellenbach, K.R., Slowik, J.G., Platt, S.M., Canonaco, F., Zotter, P., Wolf, R., Pieber, S.M., Bruns, E.A., Crippa, M., Ciarelli, G., Piazzalunga, A., Schwikowski, M., Abbaszade, G., Schnelle-Kreis, J., Zimmermann, R., Am, Z., Szidat, S., Baltensperger, U., Haddad, I.E., Prévôvt, A.S.: High secondary aerosol contribution to particulate pollution during haze events in China. Nature 514, 218-222 (2014). https://doi.org/10.1038/nature13774

Itahashi, S., Hayami, H., Uno, I., Pan, X., Uematsu, M.: Importance of coarse-mode nitrate produced via sea-salt as atmospheric input to East Asian oceans. Geophys. Res. Lett. 43, 5483-5491 (2016). https:// doi.org/10.1002/2016GL068722

Kang, J., Cho, B.C., Lee, C.B.: Atmospheric transport of water-soluble ions $\left(\mathrm{NO}_{3}{ }^{-}, \mathrm{NH}_{4}{ }^{+}\right.$and nss- $\left.\mathrm{SO}_{4}{ }^{2-}\right)$ to the southern East Sea (Sea of Japan). Sci. Total Environ. 408, 2369-2377 (2010). https://doi.org/10. 1016/j.scitotenv.2010.02.022

Kaufman, Y.J., Fraser, R.S.: The effect of smoke particles on clouds and climate forcing. Science 277, 1636-1639 (1997). https://doi.org/10.1126/science.277.5332.1636

Kim, T.-W., Lee, K., Duce, R., Liss, P.: Impact of atmospheric nitrogen deposition on phytoplankton productivity in the South China Sea. Geophys. Res. Lett. 41, 3156-3162 (2014). https://doi.org/10.1002/ 2014GL059665

Li, J., Han, Z., Yao, X.: A modeling study of the influence of sea salt on inorganic aerosol: concentration, size distribution, and deposition in the western Pacific Ocean. Atmos. Enviorn. 188, 157-173 (2018). https://doi.org/10.1016/j.atmosenv.2018.06.030

Li, W., Huang, X., Chen, Q., Wang, X., Cai, A., Zheng, A.: Primary productivity and its relationship with environmental factors in coastal waters off Haicang, Xiamen. Trop. Oceanogr. 18(3), 51-57 (1999) (in Chinese with English abstract).

Li, X., Wang, L., Ji, D., Wen, T., Pan, Y., Sun, Y., Wang, Y.: Characterization of the size-segregated watersoluble inorganic ions in the Jing-Jin-Ji urban agglomeration: spatial/temporal variability size distribution and sources. Atmos. Environ. 77, 250-259 (2013). https://doi.org/10.1016/j.atmosenv.2013.03.042

Liu, Z., Xie, Y., Hu, B., Wen, T., Xin, J., Li, X.: Size-resolved aerosol water-soluble ions during the summer and winter seasons in Beijing: formation mechanisms of secondary inorganic aerosols. Chemosphere 183, 119-131 (2017). https://doi.org/10.1016/j.chemosphere.2017.05.095

Liu, Y., Zhang, S., Fan, Q., Wu, D., Chan, P., Wang, X., Fan, S., Feng, Y., Hong, Y.: Accessing the impact of sea-salt emissions on aerosol chemical formation and deposition over Pearl River Delta. China. Aerosol Air Qual. Res. 15, 2232-2245 (2015). https://doi.org/10.4209/aaqr.2015.02.0127

Liu, Y., Zhang, T.R., Shi, J.H., Gao, H.W., Yao, X.H.: Responses of chlorophyll a to added nutrients, Asian dust, and rainwater in an oligotrophic zone of the Yellow Sea: implications for promotion and inhibition effects in an incubation experiment. J. Geophys. Res. - Biogeosci. 118(4), 1763-1772 (2013). https://doi.org/10.1002/2013JG002329

Luo, L., Yao, H., Gao, H.W., Hsu, S.C., Li, J.W., Kao, S.J.: Nitrogen speciation in various types of aerosols in spring over the northwestern Pacific Ocean. Atmos. Chem. Phys. 16, 325-341 (2016). https://doi. org/10.5194/acp-16-325-2016

Mirante, F., Salvador, P., Pio, C., Alves, C., Artiñano, B., Caseiro, A., Revuelta, M.A.: Size fractionated aerosol composition at roadside and background environments in the Madrid urban atmosphere. Atmos. Res. 138, 278-292 (2014). https://doi.org/10.1016/j.atmosres.2013.11.024

Morin, S., Savarino, J., Frey, M.M., Domine, F., Jacobi, H.-W., Kaleschke, L., Martins, J.M.F.: Comprehensive isotopic composition of atmospheric nitrate in the Atlantic Ocean boundary layer from $65^{\circ} \mathrm{S}$ to $79^{\circ}$ N. J. Geophys. Res. 114, D05303 (2009). https://doi.org/10.1029/2008JD010696

Nakamura, T., Matsumoto, K., Uematsu, M.: Chemical characteristics of aerosols transported from Asia to the East China Sea: an evaluation of anthropogenic combined nitrogen deposition in autumn. Atmos. Environ. 39, 1749-1758 (2005). https://doi.org/10.1016/j.atmosenv.2004.11.037

Neumann, D., Karl, M., Radtke, H., Matthias, V., Friedland, R., Neumann, T.: Quantifying the contribution of shipping NOx emissions to the marine nitrogen inventory- a case study for the western Baltic Sea. Ocean Sci. 16, 115-134 (2020). https://doi.org/10.5194/os-16-115-2020 
Neumann, D., Matthias, V., Bieser, J., Aulinger, A., Quante, M.: Sensitivity of modeled atmospheric nitrogen species and nitrogen deposition to variations in sea salt emissions in the North Sea and Baltic Sea regions. Atmos. Chem. Phys. 16, 2921-2942 (2016). https://doi.org/10.5194/acp-16-2921-2016

Park, G.-H., Lee, S.-E., Kim, Y., Kim, D., Lee, K., Kang, J., Kim, Y.-H., Kim, H., Park, S., Kim, T.-W.: Atmospheric deposition of anthropogenic inorganic nitrogen in airborne particles and precipitation in the East Sea in the northwestern Pacific Ocean. Sci. Total Environ. 681, 400-412 (2019). https://doi. org/10.1016/j.scitotenv.2019.05.135

Park, S.H., Song, C.B., Kim, M.C., Kwon, S.B., Lee, K.W.: Study on size distribution of total aerosol and water-soluble ions during an Asian dust storm event at Jeju Island. Korea. Environ. Monit. Assess. 93, 157-183 (2004). https://doi.org/10.1023/B:EMAS.0000016805.04194.56

Pathak, R.K., Wang, T., Wu, W.S.: Nighttime enhancement of $\mathrm{PM}_{2.5}$ nitrate in ammonia-poor atmospheric conditions in Beijing and Shanghai: plausible contributions of heterogeneous hydrolysis of $\mathrm{N}_{2} \mathrm{O}_{5}$ and $\mathrm{HNO}_{3}$ partitioning. Atmos. Environ. 45, 1183-1191 (2011). https://doi.org/10.1016/j.atmosenv.2010. 09.003

Pathak, R.K., Wu, W.S., Wang, T.: Summertime PM2.5 ionic species in four major cities of China: nitrate formation in an ammonia-deficient atmosphere. Atmos. Chem. Phys. 9, 1711-1722 (2009). https://doi. org/10.5194/acp-9-1711-2009

Prijith, S.S., Aloysius, M., Mohan, M.: Relationship between wind speed and sea salt aerosol production: A new approach. J. Atmos. Solar.-Terr. Phys. 108, 34-40 (2014). https://doi.org/10.1016/j.jastp.2013.12. 009

Qi, J.H., Shi, J.H., Gao, H.W., Sun, Z.: Atmospheric dry and wet deposition of nitrogen species and its implication for primary productivity in coastal region of the Yellow Sea. China. Atmos. Environ. 81, 600-608 (2013). https://doi.org/10.1016/j.atmosenv.2013.08.022

Qi, J., Yu, Y., Yao, X., Gang, Y., Gao, H.: Dry deposition fluxes of inorganic nitrogen and phosphorus in atmospheric aerosols over the Marginal Seas and Northwest Pacific. Atmos. Res. 245, 105076 (2020). https://doi.org/10.1016/j.atmosres.2020.105076

Rosenfeld, D., Lahav, R., Khain, A., Pinsky, M.: The role of sea spray in cleansing air pollution over ocean via cloud processes. Science 297, 1667-1670 (2002). https://doi.org/10.1126/science.1073869

Russell, K. M., Keene, W. C., Maben, J. R., Galloway, J. N.: Phase partitioning and dry deposition of atmospheric nitrogen at the mis-Atlantic U.S. coast. J. Geophys. Res. 108 (D21), 4656 (2003). https://doi. org/10.1029/2003JD003736

Seinfeld, J.H., Pandis, S.N.: Atmospheric chemistry and physics: from air pollution to climate change, $-2 \mathrm{nd}$ ed. John Wiley \& Sons, Inc., Hoboken, New Jersey. (2006)

Shi, J.H., Zhang, J., Gao, H.W., Tan, S.C., Yao, X.H., Ren, J.L.: Concentration, solubility and deposition flux of atmospheric particulate nutrients over the Yellow Sea. Deep Sea Res. Part II(97), 43-50 (2013). https://doi.org/10.1016/j.dsr2.2013.05.004

Slinn, W.G.N.: Predictions for particle deposition to vegetative surfaces canopies. Atmos. Environ. 16, 1785-1794 (1982). https://doi.org/10.1016/0004-6981(82)90271-2

Spokes, L.J., Jickells, T.D.: Is the atmosphere really an important source of reactive nitrogen to coastal waters? Continent Shelf Res. 25, 2022-2035 (2005). https://doi.org/10.1016/j.csr.2005.07.004

Srinivas, B., Sarin, M.M., Sarma, V.V.S.S.: Atmospheric dry deposition of inorganic and organic nitrogen to the Bay of Bengal: impact of continental outflow. Mar. Chem. 127, 170-179 (2011). https://doi.org/10. 1016/j.marchem.2011.09.002

Taketani, F., Aita, M.N., Yamaji, K., Sekiya, T., Ikeda, K., Sasaoka, K., Hashioka, T., Honda, M.C., Matsumoto, K., Kanaya, Y.: Seasonal response of North Western Pacific marine ecosystems to deposition of atmospheric inorganic nitrogen compounds from East Asia. Sci. Rep. 8, 9324 (2018). https://doi.org/10.1038/ s41598-018-27523-w

Tan, T., Hu, M., Li, M., Guo, Q., Wu, Y., Fang, X., Gu, F., Wang, Y., Wu, Z.: New insight into PM 2.5 pollution patterns in Beijing based on one-year measurement of chemical compositions. Sci. Total Environ. 621, 734-743 (2018). https://doi.org/10.1016/j.scitotenv.2017.11.208

Tian, S.L., Pan, Y.P., Liu, Z.R., Wen, T.X., Wang, Y.S.: Size-resolved aerosol chemical analysis of extreme haze pollution events during early 2013 in urban Beijing. China. J. Hazard. Mater. 279, 452-460 (2014). https://doi.org/10.1016/j.jhazmat.2014.07.023

Wang, H., Zhu, B., Shen, L., Xu, H., An, J., Xue, G., Cao, J.: Water-soluble ions in atmospheric aerosols measured in five sites in the Yangtze River Delta, China: size-fractionated, seasonal variations and sources. Atmos. Environ. 123, 370-379 (2015). https://doi.org/10.1016/j.atmosenv.2015.05.070

Wu, S.-P., Dai, L.-H., Wei, Y., Zhu, H., Zhang, Y.-J., Schwab, J.J., Yuan, C.-S.: Atmospheric ammonia measurements along the coastal lines of Southeastern China: Implications for inorganic nitrogen deposition to coastal waters. Atmos. Environ. 177, 1-11 (2018). https://doi.org/10.1016/j.atmosenv.2017. 12.040 
Wu, S.-P., Cai, M.-J., Xu, C., Zhang, N., Zhou, J.-B., Yan, J.-P., Schwab, J.J., Yuan, C.-S.: Chemical nature of $\mathrm{PM}_{2.5}$ and $\mathrm{PM}_{10}$ in the coastal urban Xiamen, China: insights into the impacts of shipping emissions and health risk. Atmos. Environ. 227, 117383 (2020). https://doi.org/10.1016/j.atmosenv.2020.117383

Wu, S.-P., Dai, L.-H., Zhu, H., Zhang, N., Yan, J.-P., Schwab, J.J., Yuan, C.-S.: The impact of sea-salt aerosols on particulate inorganic nitrogen deposition in the western Taiwan Strait region. China. Atmos. Res. 228, 68-76 (2019). https://doi.org/10.1016/j.atmosres.2019.05.015

Xie, R.K., Jackson, K.A., Seip, H.M., McLeod, C.W., Wibetoe, G., Schofield, M.J., Anderson, D., Hanssen, J.E.: Characteristics of water soluble inorganic chemical components in size-resolved airborne particulate matters-Sheffield. U. k. J. Environ. Monit. 11, 336-343 (2009). https://doi.org/10.1039/B805285A

Xing, J., Song, J., Yuan, H., Wang, Q., Li, X., Li, N., Duan, L., Qu, B.: Water-soluble nitrogen and phosphorous in aerosols and dry deposition in Jianzhou Bay, North China: deposition velocities, origins and biogeochemical implications. Atmos. Res. 207, 90-99 (2018). https://doi.org/10.1016/j.atmosres.2018. 03.001

Xue, D., Chen, C.-Q., Huang, L., Gao, H.-W., Liu, X.-H.: Impacts of heterogeneous reactions of nitrogencontaining gases on sea salts on nitrogen dry deposition fluxes over the China Sea. Period. Ocean Univ. China 50(5), 19-30 (2020). https://doi.org/10.16441/j.cnki.hdxb.20190143(inChinesewithEnglishabstract)

Yao, X., Zhang, L.: Chemical processes in sea-salt chloride depletion observed at a Canadian rural coastal site. Atmos. Environ. 46, 189-194 (2012). https://doi.org/10.1016/j.atmosenv.2011.09.081

Yeatman, S.G., Spokes, L.J., Jickells, T.D.: Compositions of coarse-mode aerosol nitrate and ammonium at two polluted coastal sites. Atmos. Environ. 35, 1321-1335 (2001). https://doi.org/10.1016/S13522310(00)00452-0

Yu, X., Pan, Y., Song, W., Li, S., Li, D., Zhu, M., Zhou, H., Zhang, Y., Li, D., Yu, J., Wang, X., Wang, X.: Wet and dry nitrogen depositions in the Pearl River Delta, South China: observations at three typical sites with an emphasison water soluble organic nitrogen. J. Geophys. Res. Atmos. 125, e2019JD030983 (2020). https://doi.org/10.1029/2019JD030983

Yue, D., Zhong, L., Zhang, T., Shen, J., Zhou, Y., Zeng, L., Dong, H., Ye, S.: Pollution properties of watersoluble secondary inorganic ions in atmospheric $\mathrm{PM}_{2.5}$ in the Pearl River Delta region. Aerosol Air Qual. Res. 15, 1737-1747 (2015). doi:https://doi.org/10.4209/aaqr.2014.12.0333

Zhang, J., Tong, L., Huang, Z., Zhang, H., He, M., Dai, X., Zheng, J., Xiao, H.: Seasonal variation and size distributions of water-soluble inorganic ions and carbonaceous aerosols at a coastal site in Ningbo. China. Sci. Total Environ. 639, 793-803 (2018). https://doi.org/10.1016/j.scitotenv.2018.05.183

Zhang, L., Vet, R., Wiebe, A., Mihele, C., Sukloff, B., Chan, E., Moran, M.D., Iqbal, S.: Characterization of the size-segregated water-soluble inorganic ions at eight Canadian rural sites. Atmos. Chem. Phys. 8, 7133-7151 (2008). https://doi.org/10.5194/acp-8-7133-2008

Zhang, Y., Yu, Q., Ma, W., Chen, L.: Atmospheric deposition of inorganic nitrogen to the eastern China seas and its implications to marine biogeochemistry. J. Geophys. Res. 115, D00k10 (2010). https://doi.org/ 10.1029/2009JD012814

Zhang, L., Gong, S., Padro, J., Barrie, L.: A size-segregated particle dry deposition scheme for an atmospheric aerosol module. Atmos. Environ. 35, 549-560 (2001). https://doi.org/10.1016/S1352-2310(00) 00326-5

Zhu, L., Chen, Y., Guo, L., Wang, F.: Estimate of dry deposition fluxes of nutrients over the East China Sea: the implication of aerosol ammonium to non-sea-salt sulfate ratio to nutrient deposition of coastal oceans. Atmos. Environ. 69, 131-138 (2013). https://doi.org/10.1016/j.atmosenv.2012.12.028

Zhuang, H., Chan, C.K., Fang, M., Wexler, A.S.: Size distributions of particulate sulfate, nitrate, and ammonium at a coastal site in Hong Kong. Atmos. Environ. 33, 843-853 (1999). https://doi.org/10.1016/ S1352-2310(98)00305-7

Publisher's Note Springer Nature remains neutral with regard to jurisdictional claims in published maps and institutional affiliations. 


\section{Authors and Affiliations}

Shui-Ping $\mathrm{Wu}^{1,2}$ (D) Xiang $\mathrm{Li}^{2} \cdot$ Yang Gao ${ }^{2} \cdot$ Mei-Jun Cai ${ }^{2} \cdot$ Chao Xu ${ }^{2}$ James J. Schwab ${ }^{3}$. Chung-Shin Yuan ${ }^{4}$

Shui-Ping Wu

wsp@xmu.edu.cn

1 Fujian Provincial Key Laboratory for Coastal Ecology and Environmental Studies, Xiamen University, Xiamen 361102, China

2 Center for Marine Environmental Chemistry and Toxicology, College of Environment and Ecology, Xiamen University, Xiamen 361102, China

3 Atmospheric Sciences Research Center, University at Albany, SUNY, Albany 12203, USA

4 Institute of Environmental Engineering, Sun Yat-Sen University, Kaohsiung 80424, China 